\title{
L2 Acquisition of Mandarin Zai and -Le
}

\author{
by \\ Xiner Tong \\ B.A., Minzu University of China, 2010
}

\begin{abstract}
Submitted to the Graduate Faculty of
the Dietrich School of Arts and Sciences in partial fulfillment

of the requirements for the degree of

Master of Arts
\end{abstract}

University of Pittsburgh

2012 


\section{UNIVERSITY OF PITTSBURGH \\ THE DIETRICH SCHOOL OF ARTS AND SCIENCES}

This thesis was presented

by

Xiner Tong

It was defended on

April 23 ${ }^{\text {rd }}, 2012$

and approved by

Hiroshi Nara, Professor, Department of East Asian Languages \& Literatures, University of Pittsburgh

Yi Xu, Assistant Professor, Department of East Asian Languages \& Literatures, University of Pittsburgh

Thesis Director: Yasuhiro Shirai, Professor, Department of Linguistics, University of

Pittsburgh 
Copyright (C) by Xiner Tong

2012 


\title{
L2 ACQUISITION OF MANDARIN ZAI AND -LE
}

\author{
Xiner Tong, M.A. \\ University of Pittsburgh, 2012
}

The Aspect Hypothesis (AH) has been well attested in research on L1 and L2 acquisition of Indo-European languages such as English, French, German, Italian, and Spanish (e.g., Li \& Shirai, 2000). However, studies to test the AH in the L2 acquisition of Chinese have been scarce (Jin \& Hendriks, 2005). Among the studies done of L2 acquisition of Mandarin Chinese, previous research (e.g., Duff \& Li, 2002; Jin \& Hendriks, 2005) has confirmed the AH (Andersen \& Shirai, 1994) in L2 acquisition of the aspects, including -zhe, -le, zai, -guo. Almost all previous studies used free production of the learners. The use of strictly controlled production is rare. The present study fills the gap. The present study investigates the acquisition of Mandarin aspect markers zai and -le by L2 learners of Mandarin Chinese. In two judgment tests, participants judged the use of progressive zai and perfective -le in three contexts (obligatory, incorrect, and optional). Both of the two predictions of the AH were tested: 1) Association Prediction (AP): for L2 learners, the association between progressive aspect marker zai with activity verbs is stronger than that between zai with accomplishment verbs, which in turn is stronger than that between zai and achievement verbs; the association between perfective aspect marker -le with accomplishment verbs and achievement verbs is stronger than that between -le and activity verbs, which in turn is stronger than that between -le and stative verbs. 2) Developmental Prediction (DP): learners of lower proficiency level would use progressive zai and perfective -le in a more prototypical way than learners of higher proficiency level, i.e. lower 
proficiency learners use progressive zai with activity verbs more than higher proficiency learners, and lower proficiency learners use perfective -le with accomplishment and achievement verbs more than higher proficiency learners. Meanwhile, higher-level students extend the use of progressive zai to accomplishment and achievement verbs, and extend the use of perfective -le to activity verbs. Although previous research has shown that L2 acquisition of Mandarin aspect markers confirm the two predictions of the Aspect Hypothesis, none of the conclusions were based on a controlled production. 
TABLE OF CONTENTS

PREFACE ...........................................................................................................

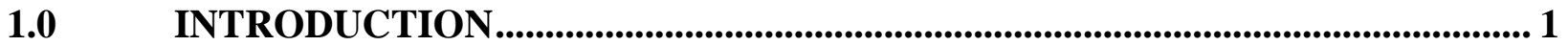

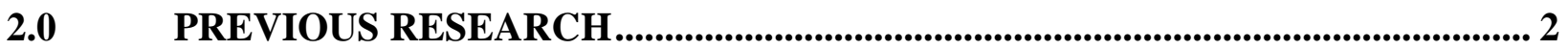

2.1 VENDLER'S LEXICAL ASPECT AND THE ASPECT HYPOTHESIS ..... 2

2.2 THE DEFAULT PAST TENSE HYPOTHESIS .............................................. 4

2.3 THE ASPECTUAL SYSTEM IN MANDARIN CHINESE ............................ 5

2.3.1 Grammatical Aspect in Mandarin Chinese.................................................... 5

2.3.2 Lexical Aspect in Mandarin Chinese ................................................................ 7

2.4 L2 ACQUISITION OF MANDARIN ASPECT MARKERS ZAI AND -LE. 9

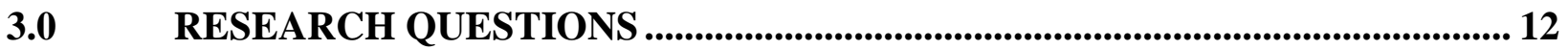

4.0 THE CURRENT STUDY ........................................................................................ 13

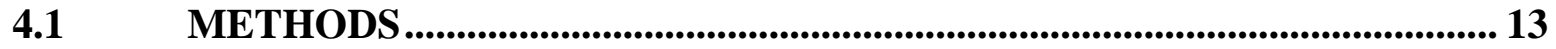

4.1.1 Participants................................................................................................... 13

4.1.2 Materials ............................................................................................................ 13

4.1.2.1 Judgment Test for Zai ........................................................................................ 14

4.1.2.2 Judgment Test for $-\mathrm{Le}$.......................................................................................... 16

4.1.2.3 Language History Questionnaire and Can-Do Test .................................... 18

4.1.3 Procedure .......................................................................................................... 18 
4.2.1 Results from the Can-Do Test...................................................................... 19

4.2.2 Results from the Native Speakers Group ............................................ 19

4.2.3 Results for Progressive Aspect Marker Zai in Obligatory Contexts...... 20

4.2.4 Results for Perfective Aspect Marker -Le in Obligatory Contexts ........ 22

4.2.5 Results for Progressive Zai And Perfective -Le in Incorrect Contexts .. 24

4.2.5.1 Results for Progressive Zai in Incorrect Contexts ...................................... 24

4.2.5.2 Results for Perfective -Le in Incorrect Contexts................................... 26

4.2.6 Results for Progressive Zai and Perfective -Le in Optional Contexts .... 27

4.2.6.1 Results for Progressive Zai in Optional Contexts ....................................... 27

4.2.6.2 Results for Perfective -Le in Optional Contexts........................................ 28

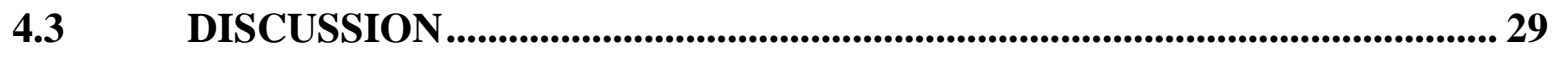

4.3.1 The Default Past Tense Hypothesis ......................................................... 29

4.3.2 The Judgments of OBL Zai with ACC and ACH in OBL Contexts ...... 30

4.3.3 The Judgments of OBL -Le with ACT and ACC in OBL Contexts....... 34

4.3.4 The Extension of the DPTH ........................................................... 36

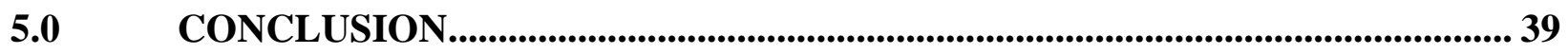

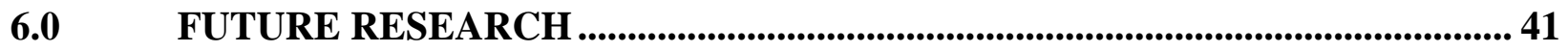

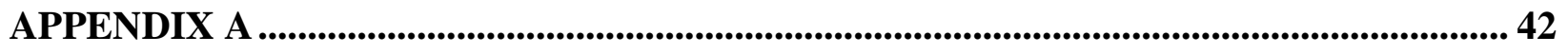

APPENDIX B .............................................................................................................................. 44

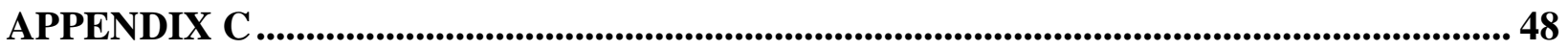

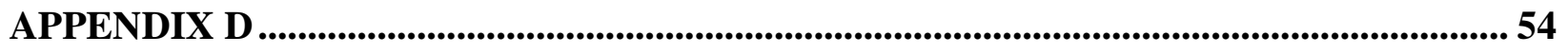

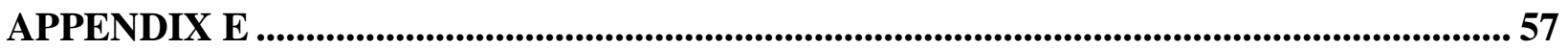




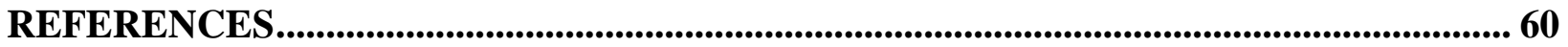




\section{LIST OF TABLES}

Table 1. Verbs Tested in the Judgment Test for Zai (in sentences)........................................ 15

Table 2. Verbs Tested in the Judgment Test for Zai (in the paragraph) ................................... 15

Table 3. Verbs Tested in the Judgment Test for - Le (in sentences)........................................ 17

Table 4. Verbs Tested in the Judgment Test for -Le (in the paragraph) .................................... 17

Table 5. Tokens of Predicates in Each Category and NSs’' Percentage Results ......................... 20

Table 6. Percentage of the Judgments of Obligatory Zai Obligatory Contexts .......................... 22

Table 7. Percentage of the Judgments of Obligatory -Le Obligatory Contexts ........................... 24

Table 8. Percentage of the Rejection of Zai in Incorrect Contexts .......................................... 25

Table 9. Percentage of the Rejection of $-L e$ in Incorrect Contexts .......................................... 27

Table 10. Percentage of the Judgments of Optional Zai in Optional Contexts........................... 28

Table 11. Percentage of the Judgments of Optional -Le in Optional Contexts.......................... 29

Table 12. Percentage of the Participants Who Judged Zai as Obligatory with Telic Verbs in

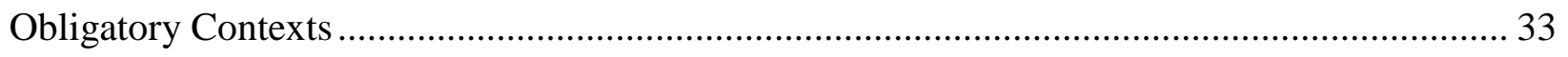

Table 13. Percentage of the Participants Who Judged -Le as Obligatory with ACT and ACC in

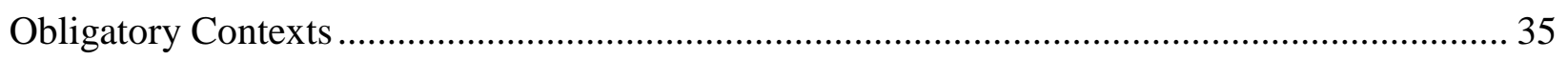

Table 14. Percentage of the Judgments of Obligatory Zai in Obligatory Contexts.................... 36 
Table 15. Percentage of Participants Who Judged Obligatory Zai with Telic Verbs in Obligatory

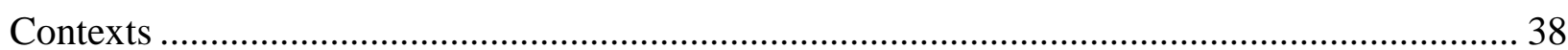




\section{LIST OF ABBREVIATIONS}

ACC: Accomplishment Verb

ACH: Achievement Verb

ACT: Activity Verb

AH: Aspect Hypothesis

AP: Association Prediction

CL: Classifier

DP: Developmental Prediction

DPTH: Default Past Tense Hypothesis

INC: Incorrect

MTS: Mixed Telic-Stative Verb

NNS: Non-Native Speaker

NS: Native Speaker

OBL: Obligatory

OP: Optional

RVC: Resultative Verb Compound

STA: Stative Verb

VCM: Cognitive-Model Predicates 


\section{PREFACE}

This is a product of many people's efforts. I thank my thesis advisor, Professor Yasuhiro Shirai, for his advice as well as his continuous patience and support. I would also like to thank my other committee members, Professor Yi Xu and Professor Hiroshi Nara, for their time and help. I would also like to thank the Chinese language instructors in East Asian Department at the University of Pittsburgh and the Chinese language instructor in Modern Languages Department at the Carnegie Mellon University for allowing me to make announcements to recruit participants in their classes. These instructors include Fan Fan, Wan-Ching Hsieh, Yiting Cheng, Cui Jie, Juchun Wei, Jing Wang, and Yan Wang. I also would like to thank my friends Katherine Martin, Nozomi Tanaka, and Zoe Luk for providing materials, and Hang Meng, Bo Zhang, Hana Wang, Qi Yang, etc. for participating in my pilot studies and helping me revise the tests. I thank all my participants for their time and support. I also thank Andy Jeske for spending time studying with me. Lastly, I would like to thank my best friends Jian Shao, Hang Meng, Bo Zhang and Jia Fang, and my dearest mother Xiaoyue Yu for their endless support and love. 


\subsection{INTRODUCTION}

Although the Aspect Hypothesis (AH) has been well attested in research on L1 and L2 acquisition of Indo-European languages such as English, French, German, Italian, and Spanish, studies to test the Aspect Hypothesis in the L1 and L2 acquisition of Chinese have been scarce (Jin \& Hendriks, 2005). This study attempts to fill the gap.

Among the studies done on L1 and L2 acquisition of Mandarin Chinese, previous research (e.g., Duff \& Li, 2002; Jin \& Hendriks, 2005) has confirmed the Aspect Hypothesis (Andersen \& Shirai, 1994) in both L1 acquisition and L2 acquisition of the aspect markers, including durative -zhe, perfective -le, progressive zai, and experiential -guo. However, almost all these studies used a free production task. For instance, the participants were elicited to tell a story according to a set of pictures, and their oral production was analyzed (e.g., Jin \& Hendriks, 2005). The use of strictly controlled paper and pencil test data is rare.

In the present study, the AH and the Default Past Tense Hypothesis (the DPTH), which is an alternative hypothesis that attempts to explain the L2 development of aspect, will be introduced. Then, two judgment tests will be reported which elicited controlled data from the participants to further confirm the Aspect Hypothesis in L2 Mandarin Chinese acquisition. 


\subsection{PREVIOUS RESEARCH}

\subsection{VENDLER'S LEXICAL ASPECT AND THE ASPECT HYPOTHESIS}

The Aspect Hypothesis is based on a four-way distinction of the inherent aspectual meaning of predicates formed by Vendler (1957). Vendler claimed that verbs have tenses in English and this fact indicates that considerations involving the concept of time are relevant to their use. He classified verbs into four lexical categories: stative verbs (STA), which indicate the action is going on timelessly, and continues without repetition unless some other force changes it (verbs such as know, like, love, etc.); activity verbs (ACT), which refer to a dynamic activity without an end-point (verbs such as run, swim, walk, etc.); achievement verbs (ACH), which characterize events that are punctual and instantaneous (verbs such as reach, recognize, notice, etc.); and accomplishment verbs (ACC), which refer to dynamic activities that have an end-point (verbs such as paint, build, make, etc.).

Based on the four-way distinction of the inherent aspectual meaning of predicates, Andersen and Shirai (1994) proposed the Aspect Hypothesis. Chen and Shirai (2010) stated that it consists of the following generalizations for the acquisition of tense-aspect markers:

A. Children first use past or perfective marking on achievement and accomplishment verbs, eventually extending its use to activity and stative verbs. B. In languages that encode the perfective/imperfective distinction, imperfective 
past develops later than perfective past.

C. In languages that have progressive aspect, children first use progressive aspect marking mostly with activity verbs, then extend to accomplishment and achievement verbs.

D. Children do not incorrectly overextend progressive aspect markings to stative verbs.

(Chen \& Shirai, 2010, p. 2)

Previous research has shown that the Aspect Hypothesis is confirmed in L1 acquisition of French, Italian, English, Turkish, Russian, Japanese, and Chinese (Chen \& Shirai, 2010). The Aspect Hypothesis in second language acquisition (Andersen \& Shirai, 1994; Bardovi-Harlig, 1994) has undergone a series of revisions similar to its development in the L1 studies (BardoviHarlig, 2002). The AH has been confirmed in previous studies in the L2 acquisition of Italian, Japanese, Portuguese, Russian, and Spanish by L1 speakers of English, Dutch, Chinese, Danish, and mixed languages (Bardovi-Harlig, 2002).

In fact, the Aspect Hypothesis has two components in its predictions-the Association Prediction and the Developmental Prediction. The Association Prediction (AP) predicts that language learners associate the perfective aspect marker more strongly with achievement verbs and accomplishment verbs than with activity verbs and stative verbs, and they associate the progressive aspect marker with activity verbs more strongly than with achievement verbs and stative verbs. The Developmental Prediction (DP) predicts that as learners' proficiency goes up, they will spread the use of the past/perfective aspect marker from achievement and accomplishment verbs to activity verbs and stative verbs, and they also will spread the use of the progressive aspect marker from activity verbs to accomplishment verbs and achievement verbs. 
Shirai (2004) proposed that there is a disconnection between the Association Prediction and the Developmental Prediction, and three generalizations have been summarized from previous studies of the acquisition of English as a second language:

1. Learners tend to use the prototypical combinations (past with punctual/telic verbs, and progressive with activity verbs) most frequently.

2. The development from prototypical to nonprototypical is not always observed in the cross-sectional and longitudinal studies that used oral or written production data. In fact, for many cases the prototypical association is stronger for the intermediate level than for the beginning level.

3. The results from the paper-and-pencil tests on the use of past tense forms in obligatory contexts are generally consistent with the prediction of the $\mathrm{AH}$, including the developmental claim (i.e., lower level learners more constrained by inherent aspect).

(Shirai, 2004, p. 101)

\subsection{THE DEFAULT PAST TENSE HYPOTHESIS}

A competing hypothesis that provides an alternative prediction to the Developmental Prediction of the AH is the Default Past Tense Hypothesis. When testing L2 learners of Spanish in classroom settings, Salaberry (e.g., Salaberry, 1999) found that for the beginning stages of acquisition, the use of past tense verbal morphology in L2 Spanish among adult tutored leaners is independent of the effect of the inherent lexical aspect value of verbal predicates. This trend has been claimed as the Default Past Tense Hypothesis, which predicts that learners initially use 
perfective past marking as a default past tense marker, and higher proficiency level learners are more restricted by inherent lexical aspect of verbal predicates. This goes against the Developmental Prediction of the AH. However, the DPTH has only been tested and verified in beginning level learners of Spanish with L1 English (Salaberry, 1999, 2003, 2011). This paper will discuss to what extent these two theories may respectively account for L2 Chinese learners' data.

\subsection{THE ASPECTUAL SYSTEM IN MANDARIN CHINESE}

Mandarin is known as a tenseless language, rich in aspectual expressions but lacking grammatical tense. In Mandarin, temporal relations are either inferred from context or typically marked with time adverbials and aspect markers (nondeictic and dependent on a speaker's viewpoint; Chen \& Shirai, 2010).

The Mandarin aspectual system has been analyzed, and sometimes contrasted with the English system, by a number of linguists (e.g., Li, 1990; Smith, 1991). Aspect markers have been studied in terms of lexical aspect and grammatical aspect (Duff \& Li, 2002).

\subsubsection{Grammatical Aspect in Mandarin Chinese}

Several grammatical aspectual distinctions and markers exist in Mandarin Chinese. Perfective markers include -le, which is for bounded events, and -guo, which indicates that action has been experienced or an event has happened. According to Jin (2006), experiential -guo is verb-final (such as in sentence (1)). Syntactically, perfective -le can appear in either verb-final (such as in 
sentence (2)) or sentence-final (such as in sentence (3)).

(1) Xiao Wang kan-GUO nachang dianying.

Little Wang see-GUO that-CHANG (CL) movie.

Little Wang has seen that movie.

(2) Xiao Wang kan-LE yichang dianying. (verb-final)

Little Wang see-LE one-CHANG (CL) movie.

Little Wang saw a movie.

(3) Xiao Wang chiwan fan-LE. (sentence-final)

Little Wang eat-finish meal-LE.

Little Wang has eaten his meal.

Imperfective markers include the progressive marker zai, a less frequently occurring postverbal durative marker zhe, and a colloquial imperfective -ne which marks durativity or progression (Bowerman \& Li, 1998). For example, in sentence (4), progressive marker zai indicates the action of eating is on-going. In sentence (5), zhe indicates the activity of watching a movie is durative. In sentence (6), the colloquial imperfective marker -ne indicates the progression of eating, and in this sentence, zai can be either used before the main verb chi 'eat', or omitted.

(4) Xiao Wang ZAI chi fan.

Little Wang ZAI eat meal.

Little Wang is eating meal.

(5) Xiao Wang kan-ZHE dianying chi fan.

Little Wang see-ZHE movie eat meal.

Little ate meal while watching a movie. 
(6) Xiao Wang (ZAI) chi fan-NE. ${ }^{1}$

Little Wang (ZAI) eat meal-NE.

Little Wang is eating meal.

\subsubsection{Lexical Aspect in Mandarin Chinese}

According to Bowerman and Li (1998), Tai (1984) examined lexical aspect in Chinese using Vendler's categorization scheme, and found that Chinese has roughly the same types of verbs as English with one striking difference: Chinese often uses resultative verb compounds (RVCs) to describe events that English specifies with accomplishment and achievement verbs. Unlike English accomplishment verbs, however, Chinese RVCs cannot be marked with the progressive marker. For example, xue 'study' in sentence (7) is an activity verb, so it is compatible with the progressive marker zai; but xue-hui 'study-know' in sentence (8) is a RVC, and so it cannot be combined with zai.

(7) Yuehan zai xue Zhongwen.

John ZAI study Chinese.

John is studying Chinese.

(8) *Yuehan zai xue-hui Zhongwen.

John ZAI study-know Chinese.

John is learning Chinese.

(Examples from Bowerman \& Li, 1998, p. 315)

Because differences exist between Chinese and English in terms of lexical aspect, the ways

${ }^{1}$ In colloquial sentences with both "zai” and “ne”, “zai” is optional, and many times omitted. 
in which different researchers classify Chinese verbs vary. Li (1990) differentiates Chinese verbs into six categories: stative verbs, activity verbs, accomplishment verbs, achievement verbs, semelfactive verbs and mixed telic-stative verbs (MTSs). Semelfactive verbs encode a punctual but not resultative situation, such as tiao 'to jump', zhayan 'to blink', etc. MTSs can describe both the actions, punctual or durative, and the stative result of the action. Therefore, they have different meanings when they are combined with the progressive marker zai and the durative marker zhe. Such verbs include chuan 'to put on/wear'; na 'to take/hold'; ti 'to pick up/carry'; gua 'to hang/is hanging'. Examples are as follows:

(9) Ta ZAI chuan pixie.

He/she ZAI put-on leather shoe.

He/she is putting on a pair of leather shoes.

(10) Ta chuan ZHE pixie.

He/she wear ZHE leather shoe.

He/she is wearing a pair of leather shoes.

(Jin \& Hendriks, 2005, p. 72)

Jin and Hendriks (2005) identify five categories: states, activities, accomplishments, achievements, and cognitive-model predicates (VCMs). The last category includes modals such as keyi 'can', dei 'have to', hui 'will', nenggou 'can', yao 'will/want' and yinggai 'must', and predicates that describe cognitive processes such as juede 'to feel', jueding 'to decide', zhidao 'to know', xiang 'to think/want' or xiang-related predicates such as xiang qilai 'suddenly remember'. Jin and Hendriks (2005) categorize the RVCs into achievement verbs in the analysis, and they did not include the VCMs in analysis. Other researchers prefer to categorize Chinese verbs into five categories: States verbs, Activities verbs, Accomplishments verbs, Achievements 
verbs, and Semelfactive verbs (Chen \& Shirai, 2010; Duff \& Li, 2002; Smith, 1991).

In this study, only Vendler's four lexical categories (STA, ACT, ACH, ACC) were included. RVCs were not included in order to test the association between progressive zai and prototypical achievements from the learners' perspective. The operational tests for the aspectual categories of predicates in Chen and Shirai (2010) were used as diagnostic tests for predicate coding (see Appendix A). Ambiguous verbs were avoided.

\section{$2.4 \quad$ L2 ACQUISITION OF MANDARIN ASPECT MARKERS ZAI AND -LE}

Studies on L2 acquisition of Mandarin Chinese aspect are scarce. Second language studies of Mandarin aspect (acquisition and use) have been conducted by Sun (1993), Eccles (1991), Christensen (1997), Teng (1998), and Wen (1995, 1997) (Duff \& Li, 2002). Wen (1995), for example, analyzed -le used by 14 English-L1 American college students at beginner and advanced levels. Perfective -le was produced most often with the verbs wang 'to forget', chi 'to eat', he 'to drink', and mai 'to buy'. Perfective -le was produced consistently with the RVC wan 'finished' (even when it is only optional); and in combination with the time adverbs yihou 'after' and yiqian 'formerly', signaling the boundedness of events. Wen (1995) surmised that these adverbs and complements serve as semantic cues or frames for learners triggering verb-final -le marking (sometimes incorrectly). Use of perfective -le with past actions often followed a past time adverb such as zuotian 'yesterday,' which was attributed to L1 transfer (-le used as a past

tense marker) because the non-native speakers were less likely to mark actions to be completed in the present or future with -le.

Jin and Hendriks (2005) elicited data (using story-telling) from 30 L2 Chinese learners, 30 
L1 Chinese learners and 10 Chinese adults with two sets of picture sequences: a horse story and a cat story. The results showed that the L1 acquisition confirms the prediction of the Aspect Hypothesis, although some sporadic cases of over-generalization of zai to states and zhe to achievements were found. The results suggested that the [ttelic] distinction is crucial in the L1 acquisition of Chinese aspect markers. For the L2 learners, their preference of the association of Verb Final-le with achievements is much stronger at the beginning than the youngest L1 group and the spread of its use to activities appears from the beginning. Moreover, the results of L2 learners strongly indicate an influence of L1 transfer. They concluded that both the L1 and L2 Chinese learners in this study behave more or less in the same way as predicted by the Aspect Hypothesis. Telicity seems to be playing a vitally important role in the L1 acquisition of Chinese aspect markers. Its importance in the L2 acquisition of these aspect markers is partly obscured by evidence indicating the influence of the learners’ L1, English.

Duff and Li (2002) used three tasks to collect data from participants (including native speakers (NSs) and non-native speakers (NNSs)), including an oral video-story retelling, a personal narrative of vacation travel, and a written editing task of a past narrative. After comparing the performance of these NSs and NNSs on three tasks in this study, they summarized that NNSs--particularly those with low proficiency levels--tended to undersupply -le in their oral narratives, omitting it in certain obligatory contexts, and tended to oversupply it with certain stative and non-perfective activity verbs. They believe that a number of interrelated and interacting factors are responsible for the observed production (or omission) of the perfective verb-final le in Mandarin: 1) L1 transfer from the English grammatical category 'past tense,' and thus sensitivity toward marking past events grammatically, and to using a verb-final morpheme like -ed that marks past events (and/or perfective aspect); 2) cognitive factors or operating 
principles related to the functional/multifunctional load of $l e$, with both perfective and perfect/inchoative meanings, given its relative frequency, perceptual saliency, and transparency; and the possible "priming" role of certain adverbials connected with -le use; 3) input factors, including NS variability, resulting from viewpoint, stylistic preferences, register, and variation across dialects (e.g., Taiwanese vs. Standard Mainland Mandarin), as well as frequency of exposure to forms/functions; 4) the relationship between -le acquisition/use and types of lexical items and constructions it typically co-occurs with, such as RVCs with inherent perfectivity; 5) discourse/narrative or task contexts, such as the pear story, which involves certain kinds of actions and events and temporal relations; and 6) the effect of instruction and textbook explanations on the acquisition of aspect.

Most of the previous work used free production data, i.e. participants produce narratives or stories according to instructions or pictures. Only two studies used controlled production. One is the written editing task of a past narrative ${ }^{2}$ used by Duff and Li (2002), which does not support the Aspect Hypothesis. The other study is Jin (2006), which used an Acceptability Judgment Test (AJT). The AJT elicits controlled data by asking participants to judge if the Chinese sentences were acceptable on four scales. The Aspect Hypothesis was supported by Jin (2006) overall but not by the AJT.

Since the Aspect Hypothesis has been confirmed in most of the studies using free production data, controlled data were elicited by using Judgment Tests of zai and -le to test the Aspect Hypothesis in L2 Mandarin Chinese acquisition in the present study.

2 Task 3 was a written editing task of a past narrative that contained no aspect marking on verbs. Participants were to supply missing LE markers where needed after they had read through the passage for the first time. The task was accompanied by an audio-recorded "think-aloud" procedure (in either Mandarin or English) to capture their metalinguistic awareness of, and reasons for, supplying LE in particular contexts. (Duff \& Li, 2002) 


\subsection{RESEARCH QUESTIONS}

The following research questions guided this study:

1. Will the Association Prediction of the Aspect Hypothesis be confirmed in the L2 acquisition of Mandarin Chinese aspect markers zai and -le? That is to say, will lower-level learners of L2 Chinese use the progressive zai more with ACT, and less with ACC and ACH? Will lower-level learners of L2 Chinese use the perfective -le more with ACC and ACH, and less with ACT and STA?

2. Will the Developmental Prediction of the Aspect Hypothesis be confirmed in the L2 acquisition of Mandarin Chinese aspect markers zai and -le? That is to say, will lower-level learners of L2 Chinese use lexical aspect markers zai and -le in a more prototypical way than higher-level learners? In other words, as learners' proficiency goes up, will they spread the use of progressive zai to ACC and ACH, and spread the use of -le to ACT and STA? 


\subsection{THE CURRENT STUDY}

\subsection{METHOD}

\subsubsection{Participants}

Twenty second-year learners of Chinese, 20 third-year learners of Chinese, and 20 native speakers of Mandarin Chinese participated in this study. Among the participants in this study, 32 of the learners of Mandarin Chinese were students from University of Pittsburgh, and 8 were students from Carnegie Mellon University. Native Chinese speakers in this study were all living in China and were all in their twenties. Eight of them were graduate students (three studying sciences and five studying humanities and social sciences). Others were journalists, editors, or working in government, etc. All the native speakers spoke standard Mandarin Chinese, although some of them were from Northern China, where most people speak standard Mandarin (or the dialects are not too different from standard Mandarin Chinese), and some were from Southern China, where the dialects are more diverse.

\subsubsection{Materials}

Two judgment tests (one is for zai and one is for -le) were used to elicit the judgments of using zai and -le from the participants. One questionnaire was used to investigate the 
linguistic/language background of the participants, and one can-do test was used to investigate students’ self-rated Chinese language proficiency.

The judgment tests were created by myself. Then, three native Mandarin Chinese speakers (different from the participants) were asked to take the tests. Every sentence was discussed by us to make sure that the items were valid, i.e. the use of the items was consistent with native speakers' intuition. After that, Five other native Mandarin Chinese speakers were asked to do a pilot study to confirm that the sentences and contexts are valid and accepted by native Mandarin Chinese speakers.

\subsubsection{Judgment Test for Zai}

There were 42 sentences (42 blanks) and one paragraph (11 blanks) in this test. Verbs of Vendler's four categories were included (See Appendix B for the test and English translation). In each category, three contexts were included: the use of zai was obligatory; the use of zai was incorrect; the use of zai was optional. In Mandarin Chinese, progressive zai and stative verbs are incompatible; hence no obligatory and optional zai for stative verbs was included in the test. For each blank, participants needed to judge if zai was obligatory, incorrect, or optional. If they thought zai was obligatory, they needed to write Chinese character ZAI (在) in the blank, if incorrect, they wrote ø; if optional, they wrote OP in the blank. For example, in sentence (11), participants needed to judge if zai was obligatory, incorrect, or optional in this blank, and write

Chinese character ZAI (在), or ø, or OP accordingly. In this sentence, zai is obligatory, so if the participants judged it correctly, they should have written Chinese character ZAI (在) in the blank.

\section{（11）昨天小王给我打电话的时候我 [ ]工作。}


when Little Li called me yesterday, I was [ ] working

Verbs included in sentences are categorized and listed in Table 1.

Table 1: Verbs Tested in the Judgment Test for Zai (in sentences)

\begin{tabular}{|c|c|c|c|}
\hline & Obligatory & Incorrect & Optional \\
\hline Stative & N/A & $\begin{array}{l}\text { cunzai 'to exist', } \\
\text { xiang 'to resemble', } \\
\text { zhu 'to live', zhidao } \\
\text { 'to know', qian 'to } \\
\text { owe', xihuan 'to } \\
\text { like', shi 'to be', } \\
\text { juede 'to feel', you } \\
\text { 'to have', zhu 'to } \\
\text { live', zuozai yizi } \\
\text { shang 'to sit in a } \\
\text { chair', zhanzai } \\
\text { zhuozi shang 'to } \\
\text { stand on a desk' }\end{array}$ & N/A \\
\hline Activity & $\begin{array}{l}\text { gongzuo 'to work', } \\
\text { chi 'to eat', du 'to } \\
\text { read', youyong 'to } \\
\text { swim' }\end{array}$ & $\begin{array}{l}\text { shui 'to sleep', } \\
\text { gongzuo 'to work', } \\
\text { chi 'to eat' }\end{array}$ & $\begin{array}{l}\text { youyong 'to swim', } \\
\text { pao 'to run', } \\
\text { huaquan 'to go row- } \\
\text { boating' }\end{array}$ \\
\hline Accomplishment & $\begin{array}{l}\text { shang louti 'to go } \\
\text { upstairs', mai 'to } \\
\text { buy', zouchu 'to get } \\
\text { out of', mai 'to sell' }\end{array}$ & $\begin{array}{l}\text { paojin 'to run into', } \\
\text { mai 'to buy', mai 'to } \\
\text { sell', zouchu 'to get } \\
\text { out of' }\end{array}$ & $\begin{array}{l}\text { mai 'to buy', shang } \\
\text { louti 'to go } \\
\text { upstairs', zouchu 'to } \\
\text { get out of' }\end{array}$ \\
\hline Achievement & $\begin{array}{l}\text { qifei ['plane' take } \\
\text { off'], dagu 'to play } \\
\text { the drum', sa 'to } \\
\text { spill', reng 'to } \\
\text { throw away' }\end{array}$ & $\begin{array}{l}\text { ying 'to win', shu } \\
\text { 'to lose', kaishi 'to } \\
\text { begin', dao 'to } \\
\text { arrive' }\end{array}$ & $\begin{array}{l}\text { wen 'to ask', reng } \\
\text { 'to throw' }\end{array}$ \\
\hline
\end{tabular}

Verbs tested in the paragraph are categorized and listed in Table 2.

Table 2: Verbs Tested in the Judgment Test for Zai (in the paragraph)

\begin{tabular}{|l|l|l|l|}
\hline & \multicolumn{1}{|c|}{ Obligatory } & \multicolumn{1}{|c|}{ Incorrect } & \multicolumn{1}{c|}{ Optional } \\
\hline Stative & N/A & $\begin{array}{l}\text { zhidao 'to know', you } \\
\text { 'to have', zhu 'to live' }\end{array}$ & N/A \\
\hline Activity & N/A & N/A & $\begin{array}{l}\text { lüxing 'to travel', shui } \\
\text { 'to sleep' }\end{array}$ \\
\hline Accomplishment & N/A & N/A & N/A \\
\hline Achievement & N/A & $\begin{array}{l}\text { ting 'to stop', zuo } \\
\text { huoche 'to take a }\end{array}$ & dao 'to arrive' \\
\hline
\end{tabular}




\begin{tabular}{|l|l|l|}
\hline & $\begin{array}{l}\text { train', dao 'to arrive', } \\
\text { qu 'to go to' }\end{array}$ & \\
\hline
\end{tabular}

\subsubsection{Judgment Test for $-L e$}

There were 47 sentences (48 blanks) and one paragraph (11 blanks) in this test. Verbs of Vendler's four categories were included. In each category, three contexts were included: the use of -le was obligatory; the use of -le was optional; the use of -le was incorrect (See Appendix C for the test and English translation). For each blank, participants needed to judge if -le is obligatory, incorrect, or optional. If they thought -le was obligatory, they needed to write the Chinese character $L E$ (了) in the blank, if incorrect, they wrote ø; if optional, they wrote OP in the blank. For example, in sentence (12), participants needed to judge if -le is obligatory, incorrect, or optional in this blank, and write Chinese character $L E$ (了), ø, or OP accordingly. In this sentence, -le is incorrect, so if the participants judged it correctly, they should have written ø in the blank.

（12）去年我是 [ ] 高中生。

Last year I was [ ] a high school student 
Verb tested in sentences are categorized and listed in Table 3.

Table 3: Verbs Tested in the Judgment Test for -Le (in sentences)

\begin{tabular}{|l|l|l|l|}
\hline Stative & \multicolumn{1}{|c|}{ Obligatory } & \multicolumn{1}{c|}{ Incorrect } & \multicolumn{1}{c|}{ Optional } \\
\hline Activity & $\begin{array}{l}\text { zhu 'to live', zhidao } \\
\text { 'to know', qian 'to } \\
\text { owe', xihuan 'to } \\
\text { like' }\end{array}$ & $\begin{array}{l}\text { shi 'to be', shuyu 'to } \\
\text { belong to', juede 'to } \\
\text { feel', xuyao 'to } \\
\text { need' }\end{array}$ & $\begin{array}{l}\text { xihuan 'to like', you } \\
\text { to have', qian 'to } \\
\text { owe', zhidao 'to } \\
\text { know' }\end{array}$ \\
$\begin{array}{l}\text { gongzuo 'to work', } \\
\text { chi 'to eat', kan 'to } \\
\text { watch', youyong 'to } \\
\text { swim' }\end{array}$ & $\begin{array}{l}\text { xue 'to study', shui } \\
\text { 'to sleep', gongzuo } \\
\text { to work', chi 'to } \\
\text { eat' }\end{array}$ & $\begin{array}{l}\text { guangjie 'to go } \\
\text { shopping', lüxing } \\
\text { 'to travel', pao 'to } \\
\text { run', huachuan 'to } \\
\text { go row-boating' }\end{array}$ \\
\hline Accomplishment & $\begin{array}{l}\text { xie ershi ge zi 'to } \\
\text { write 20 characters', } \\
\text { mai 'to buy', paojin } \\
\text { 'to run into', } \\
\text { shanglou 'to go } \\
\text { upstairs' }\end{array}$ & $\begin{array}{l}\text { mai 'to buy', paojin } \\
\text { shanglou 'to go } \\
\text { upstairs', zouchu 'to } \\
\text { get out of' }\end{array}$ & $\begin{array}{l}\text { jueding 'to decide', } \\
\text { mai 'to buy', paojin } \\
\text { to run into', } \\
\text { shanglou 'to go } \\
\text { upstairs' }\end{array}$ \\
\hline $\begin{array}{l}\text { qu 'to go to', } \\
\text { wenhao 'to say hi', } \\
\text { sa 'to spill', } \\
\text { zhuangdao 'to } \\
\text { knock-down' }\end{array}$ & $\begin{array}{l}\text { zuoche 'to take a } \\
\text { bus', qing 'to } \\
\text { invite', kaishi 'to } \\
\text { begin', qifei '(plane) } \\
\text { take off' }\end{array}$ & $\begin{array}{l}\text { kaishi 'to begin', } \\
\text { wen 'to ask', qing } \\
\text { to invite', ying 'to } \\
\text { win' }\end{array}$ \\
\hline
\end{tabular}

Verbs tested in the paragraph are categorized and listed in table 4.

Table 4: Verbs Tested in the Judgment Test for -Le (in the paragraph)

\begin{tabular}{|l|l|l|l|}
\hline & \multicolumn{1}{|c|}{ Obligatory } & \multicolumn{1}{c|}{ Incorrect } & \multicolumn{1}{c|}{ Optional } \\
\hline Stative & zhidao 'to know' & zhu 'to live' & you 'to have' \\
\hline Activity & shui ‘to sleep' & gongzuo 'to work' & pao 'to run' \\
\hline Accomplishment & N/A & N/A & N/A \\
\hline Achievement & $\begin{array}{l}\text { ting 'to stop', qu 'to } \\
\text { go to' }\end{array}$ & $\begin{array}{l}\text { zuo huoche 'to take } \\
\text { a train' }\end{array}$ & $\begin{array}{l}\text { qu 'to go to', dao } \\
\text { to arrive' }\end{array}$ \\
\hline
\end{tabular}

The distribution of verbs tested in the judgment tests were to a large extent balanced both 
in terms of the four categories and of the three contexts. In the sentences for -le, the verbs in each of the four categories were 12 tokens in total. In the sentences for zai, there were 10 tokens for ACT and ACH respectively, and 11 tokens for STA and ACC respectively. There were some differences in the paragraphs, because the number was relevantly hard to control in composing the paragraph. The difference, however, was very small. Therefore it did not affect the validity of test. To balance the items to the largest extent, no ACC were included in either paragraphs.

\subsubsection{Language History Questionnaire and Can-do Test}

In the language history questionnaire (Tokowicz, Michael, \& Kroll, 2004), participants needed to answer questions about their first language, second languages, and traveling history to other countries, etc. The Can-do Test (Luk, 2010; adapted from Clarke, 1981) evaluated participants’ speaking ability with fourteen questions, and listening comprehension with twelve questions. There were three scales (3-quite easy, 2-with some difficulty, 1-with great difficulty or not at all) for each question for participants to choose from. Questions included say the days of the week (for speaking), and understand very simple statements or questions in the language ("Hello", “How are you?”, “What is your name?”, “Where do you live?”, etc.) (for listening).

\subsubsection{Procedure}

For the learners of Mandarin Chinese, the researcher met each participant individually in a conference room in the Department of East Asian Languages and Literatures at the University of Pittsburgh. The total procedure to each participant took about half an hour. Half of the participants did the judgment test for -le first and then did the test for zai. The other half of the participants did reversely to avoid the possible effects on the second test from doing the first test. 
The participants were allowed to ask questions about vocabulary they did not know. The two tests took about twenty minutes to finish. After finishing the judgment tests, the questionnaire for language history information and the Can-do Test followed up. It took each participant 10 minutes to finish. After all the tests and questionnaires, four participants from each year were randomly selected and interviewed to ask about their thoughts on the two lexical aspect markers and discuss some questions on the tests.

For native Mandarin Chinese speakers, the two judgment tests were sent to the researcher's contacts in China through email, and they helped me recruit 20 participants. All 20 native speakers finished an electronic version of the judgment tests and sent them back through email. The instructions on the electronic version of the tests for these native speakers were in Chinese.

\subsection{DATA ANALYSIS}

\subsubsection{Results from the Can-Do Test}

An independent-samples t-test was conducted to compare the proficiency of $2^{\text {nd }}$ year learner group and $3^{\text {rd }}$ year learner group. There was a significant difference in the scores for $2^{\text {nd }}$ year learners' proficiency $(M=53, S D=5.4)$ and $3^{\text {rd }}$ year learners' proficiency $(M=61.4, S D=8.1)$ conditions; $t(38)=-3.85, p<.001$. These results showed that $3^{\text {rd }}$ year participants' self rated proficiency is higher than $2^{\text {nd }}$ year participants. 


\subsubsection{Results from the Native Speakers Group}

The data from 20 native speakers (see Table 5) showed that in each category of the predicates (STA, ACT, ACC, and ACH), they chose more than 95\% of zai as obligatory in obligatory zai contexts, and they judged that zai is incorrect at a percentage of higher than $92 \%$ in incorrect zai contexts. Similarly, these native speakers judged $90 \%$ or more than $90 \%$ of -le as obligatory in obligatory -le contexts, and they chose -le as incorrect in more than $90 \%$ of incorrect contexts as well. For optional zai and -le contexts, native speakers chose them as optional at a percentage of more than 58\%. Therefore, both of the judgment tests for zai and for -le were valid.

Table 5: Tokens of Predicates in Each Category and NSs’ Percentage Results

\begin{tabular}{|c|c|c|c|c|c|c|}
\hline Tokens & \multicolumn{3}{|c|}{ STA } & \multicolumn{3}{c|}{ ACT } \\
\hline zai & OBL (0) & INC (14) & OP (0) & OBL (5) & INC (3) & OP (5) \\
\hline NS & - & $100 \%$ & - & $98 \%$ & $96.7 \%$ & $58 \%$ \\
\hline$-l e$ & OBL (5) & INC (5) & OP (5) & OBL (5) & INC (5) & OP (5) \\
\hline NS & $91 \%$ & $97 \%$ & $59 \%$ & $93 \%$ & $90 \%$ & $71 \%$ \\
\hline Tokens & & ACC & & & ACH & \\
\hline zai & OBL (4) & INC (4) & OP (3) & OBL (4) & INC (8) & OP (3) \\
\hline NS & $95 \%$ & $92.5 \%$ & $76.7 \%$ & $96.3 \%$ & $95.6 \%$ & $65 \%$ \\
\hline$-l e$ & OBL (4) & INC (4) & OP (4) & OBL (6) & INC (5) & OP (6) \\
\hline NS & $90 \%$ & $90 \%$ & $70 \%$ & $95.8 \%$ & $92 \%$ & $62.5 \%$ \\
\hline
\end{tabular}

Note: NS = Native Speakers; OBL = Obligatory; INC = Incorrect; OP = Optional. 


\subsubsection{Results for Progressive Aspect Marker Zai in Obligatory Contexts}

In the judgment test for progressive zai, each test contains five blanks in which zai is obligatory before an ACT, four blanks in which zai is obligatory before an ACC, and four blanks in which zai is obligatory before an ACH. Data from 20 second-year learners of Mandarin Chinese showed that they judged zai as obligatory with $63 \%$ of the ACT (see Table 6), which was much higher than the percentages of ACC and ACH (37.5\% and 46.25\%, respectively).

Third-year learners of Mandarin Chinese showed the same pattern. They judged zai as obligatory with $73 \%$ of the ACT, $38.75 \%$ of the ACC, and $65 \%$ of the ACH. Although third-year learners of Mandarin Chinese showed a relatively strong association between progressive zai and ACH (65\%), the association between progressive zai with ACT was still the strongest (73\%). It supports the Association Prediction of the Aspect Hypothesis, which predicts that learners associate progressive aspect marker most strongly with ACT. Compared to learners, native speakers evenly associate progressive zai with ACT, ACC, and ACH. The percentages are 98\%, 95\%, and 96.25\% respectively. Because progressive zai and STA are incompatible, there was no obligatory zai included in the test.

However, when comparing the second-year learner group and the third-year learner group, the third-year students showed a stronger association between progressive zai and ACT (73\%) than the second-year students (63\%). It does not support the Developmental Prediction of the Aspect Hypothesis, which predicts that higher-level learners use progressive aspect marker in a less prototypical way than lower level learners. Because the third-year learners of Mandarin Chinese judged zai as obligatory with $73 \%$ of the ACT in obligatory contexts, while the secondyear learners of Mandarin Chinese judged zai as obligatory with 63\% of the ACT in obligatory contexts, the third-year students used progressive zai in a more prototypical way than the second- 
year students did. However, the third-year students tended to be more native-like overall, especially when using progressive zai with ACH.

Table 6: Percentage of the Judgments of Obligatory Zai in Obligatory Contexts

\begin{tabular}{|c|c|c|c|c|}
\hline Tokens & STA (0) & ACT (5) & ACC (4) & ACH (4) \\
\hline $\mathbf{2}^{\text {nd }}$ Year & - & $63 \%$ & $37.5 \%$ & $46.25 \%$ \\
\hline $\mathbf{3}^{\text {rd }}$ Year & - & $73 \%$ & $38.75 \%$ & $65 \%$ \\
\hline NS & - & $98 \%$ & $95 \%$ & $96.25 \%$ \\
\hline
\end{tabular}

Note: Zero blanks needing an obligatory zai were with STA; five blanks needing an obligatory zai were with ACT; four blanks needing an obligatory zai were with ACC; and four blanks needing an obligatory zai were with ACH.

\subsubsection{Results for Perfective Aspect Marker -Le in Obligatory Contexts}

In the judgment test for progressive -le, each test contained give blanks in which -le is obligatory after STA, five blanks in which -le is obligatory after ACT, four blanks in which -le is obligatory after ACC, and six blanks in which -le is obligatory after ACH.

Data from 20 second-year learners of Mandarin Chinese show that the participants chose -le as obligatory with $43.8 \%$ of the ACC in obligatory contexts and $58.2 \%$ of the ACH in obligatory contexts (see Table 7). Both of the two percentages were lower than the percentage of ACT (60\%). The second-year learners also used perfective -le less with ACC (43.8\%) than with STA (48\%). It did not support the Association Prediction of the Aspect Hypothesis, which 
predicts that learners associate perfective -le most strongly with ACC and $\mathrm{ACH}$, and the association between perfective -le and STA should be the weakest.

Data from the third-year learners of Mandarin Chinese did not support the Association Prediction either. They judged -le as obligatory with $62.5 \%$ of the ACC in obligatory contexts and $65.8 \%$ of ACH in obligatory contexts. The strongest association was between perfective -le and ACT (67\%). The percentage of STA (64\%) was higher than the percentage of ACC (62.5\%). Overall, the third-year learners of Mandarin Chinese judged perfective -le as obligatory with each category of verbs relatively evenly and the pattern was very much native-like. It did not support the Association Prediction of the Aspect Hypothesis, which predicts that learners should associate perfective -le mostly with ACC and ACH, the least with STA. Compared to learners, native speakers more evenly associated progressive -le with STA, ACT, ACC and ACH. The percentages were $91 \%, 93 \%, 90 \%$, and $95.8 \%$ respectively.

When comparing the second-year learner group and the third-year learner group, the thirdyear students showed a stronger association between perfective -le and ACC and ACH than the second-year students. This did not support the Developmental Prediction of the Aspect Hypothesis, which predicts that higher-level learners use perfective aspect marker in a less prototypical way than lower level learners do. Because the third-year learners of Mandarin Chinese judged obligatory -le with $62.5 \%$ of the ACC and $65.8 \%$ of the ACH in obligatory contexts, while the second-year Chinese language learners judged obligatory -le with $43.8 \%$ of the ACC and $58.2 \%$ of the ACH, the third-year students used perfective -le in a more prototypical way. This result supported the Default Past Tense Hypothesis (DPTH) (e.g., Salaberry, 2011), which predicts that L2 learners use a default marker of past tense at the beginning stage of acquisition. In this stage, the use of past tense marker among adult learners is 
independent of the effect of inherent lexical aspectual value of verbal predicates (Salaberry, 1999). Thus, L2 learners of Mandarin Chinese use perfective aspect marker -le as their default past tense markers at a lower proficiency level, which leads to a less prototypical use of -le. As the learners' proficiency goes up, their use of perfective -le becomes more prototypical. After they reach a highly advanced level, their use of -le will become less prototypical again and more native-like.

Table 7: Percentage of the Judgments of Obligatory - $L e$ in Obligatory Contexts

\begin{tabular}{|c|c|c|c|c|}
\hline Tokens & STA (5) & ACT (5) & ACC (4) & ACH (6) \\
\hline $\mathbf{2}^{\text {nd }}$ Year & $48 \%$ & $60 \%$ & $43.8 \%$ & $58.2 \%$ \\
\hline $\mathbf{3}^{\text {rd }}$ Year & $64 \%$ & $67 \%$ & $62.5 \%$ & $65.8 \%$ \\
\hline NS & $91 \%$ & $93 \%$ & $90 \%$ & $95.8 \%$ \\
\hline
\end{tabular}

Note: Five blanks needing an obligatory -le are with STA; five blanks needing an obligatory -le are with ACT; four blanks needing an obligatory -le are with ACC; and six blanks needing an obligatory -le are with ACH.

\subsubsection{Results for Progressive Zai and Perfective -Le in Incorrect Contexts}

\subsubsection{Results for Progressive Zai in Incorrect Contexts}

Another interesting point in the results is that for progressive zai in incorrect context, the secondyear learners of Mandarin Chinese were able to reject incorrect uses of zai more than the thirdyear learners did in all four categories (see Table 8). Second-year learners rejected $85.36 \%$ of the incorrect uses of zai with STA in incorrect contexts, while the third-year students rejected $80 \%$. Second-year learners rejected $83.33 \%$ of the incorrect uses of zai with ACT in incorrect contexts while the third-year learners rejected $66.67 \%$. Second-year learners rejected $58.75 \%$ of incorrect zai with ACC in incorrect contexts, while the third-year learners rejected $48.75 \%$. Second-year 
learners rejected $70 \%$ of incorrect zai with $\mathrm{ACH}$ in incorrect contexts, while the third-year learners rejected $68.13 \%$.

Table 8: Percentage of the Rejection of Zai in Incorrect Contexts

\begin{tabular}{|c|c|c|c|c|}
\hline Tokens & STA (14) & ACT (3) & ACC (4) & ACH (8) \\
\hline $\mathbf{2}^{\text {nd }}$ Year & $85.36 \%$ & $83.33 \%$ & $58.75 \%$ & $70 \%$ \\
\hline $\mathbf{3}^{\text {rd }}$ Year & $80 \%$ & $66.67 \%$ & $48.75 \%$ & $68.13 \%$ \\
\hline NS & $100 \%$ & $96.67 \%$ & $92.50 \%$ & $95.63 \%$ \\
\hline
\end{tabular}

From the percentage, we can see that the difference for ACH is not large. An independentsamples t-test was conducted to compare the second-year and the third-year participants' rejection of zai with ACH. There was no significant difference in the scores for the second-year $(\mathrm{M}=5.6, \mathrm{SD}=1.5)$ and the third-year $(\mathrm{M}=5.6, \mathrm{SD}=1.9) ; t(38)=.27, p=0.78$. These results suggest that there was no significant improvement between the second-year group and the thirdyear group regarding the correct rejection of zai used with ACH in incorrect contexts. Because third-year learners did not reject the use of zai with ACT more frequently than second-year learners even though zai was incorrect in these contexts, we can see that third-year learners are not becoming more native-like, at least when comparing group data.

However, there seem to be differences between the two groups when looking at the results of ACT and ACC. An independent-samples t-test was conducted to compare $2^{\text {nd }}$ year and 
$3^{\text {rd }}$ year participants' rejection of zai with ACT. The scores for the second-year $(\mathrm{M}=2.50, \mathrm{SD}=$ $.61)$ and the third-year $(\mathrm{M}=2.00, \mathrm{SD}=.65) ; t(38)=2.52, p=0.01$ showed that third-year learners rejected the use of zai with ACT less, even in incorrect contexts. For ACC, the mean for the second-year students was $M=2.35$, and the mean for the third-year students was $M=1.95$. The results again showed that $3^{\text {rd }}$ year learners rejected the use of zai with ACC less, even when zai was incorrect in the contexts.

The use of zai with ACT and ACC is supposed to be more prototypical according to the $\mathrm{AH}$, but the second-year learners reject it more for ACT and ACC. They probably are not sure if they can use zai regardless of context. On the other hand, the third-year students reject the more prototypical ones (ACT and ACC) less because they are now more comfortable with the use of zai with ACT and ACC. In that sense, the third-year students are more native like. This supports the pattern of DTPH, which predicts that higher-level L2 learners are more restricted by lexical aspect, i.e. learners' lexical sensitivity develops as their proficiency improves.

\subsubsection{Results for Perfective -Le in Incorrect Contexts}

The results for the incorrect use -le are different (see Table 9). The third-year learners of Mandarin Chinese rejected more incorrect use of -le with STA (81\%) than the second-year learners (73\%) in incorrect contexts. For the other three categories of predicates, the third-year learners and the second-year learners behaved similarly. The percentages of rejection of incorrect -le with ACT for the second-year and the third-year learners were $50 \%$ and $51 \%$ respectively. For ACC, the percentages were the same (46.25\%). For ACH, the percentages were $45 \%$ (second-year) versus 43\% (third-year). These results showed that the third-year learners reject -le with ACH (which is a prototypical use) less, and reject -le with STA (which is a non-prototypical use) more; hence we can see that the third-year students are more comfortable with using -le with 
$\mathrm{ACH}$, but less comfortable with STA. Thus, the third-year learners are more restricted by lexical aspect. Because the Developmental Prediction predicts that higher-level learners will be less restricted by lexical aspect, the results do not support the Development Prediction of the AH.

Table 9: Percentage of the Rejection of -Le in Incorrect Contexts

\begin{tabular}{|c|c|c|c|c|}
\hline Tokens & STA (5) & ACT (5) & ACC (4) & ACH (5) \\
\hline $\mathbf{2}^{\text {nd }}$ Year & $73 \%$ & $51 \%$ & $46.25 \%$ & $45 \%$ \\
\hline $\mathbf{3}^{\text {rd }}$ Year & $81 \%$ & $50 \%$ & $46.25 \%$ & $43 \%$ \\
\hline NS & $97 \%$ & $90 \%$ & $90 \%$ & $92 \%$ \\
\hline
\end{tabular}

\subsubsection{Results for Progressive Zai and Perfective -Le in Optional Contexts}

\subsubsection{Results for Progressive Zai in Optional Contexts}

For progressive zai in optional contexts, data from the NS group showed that they judged zai as optional in more than half of the optional contexts (59\% with ACT, 76.67\% with ACC, and 65\% with ACH; see Table 10). Because in Chinese, progressive zai cannot co-occur with STA, no STA was included in optional contexts. For learners of Chinese, the third-year group judged 38\% of zai as obligatory in optional contexts with ACT, while the second-year group judged $27 \%$ of zai as obligatory, which is lower than the third-year learners. This showed that the third-year learners associate progressive zai with ACT more than the second-year learners. This did not support the Developmental Prediction of the AH. Moreover, the second-year learners judged zai 
as obligatory in optional contexts with $41.67 \%$ of the ACC, which was much higher than that with ACT (27\%). This did not follow the pattern of the Association Prediction of the AH.

Table 10: Percentage of the Judgments of Optional Zai in Optional Contexts

\begin{tabular}{|c|c|c|c|c|c|c|c|c|c|}
\hline Tokens & \multicolumn{3}{|c|}{ ACT (5) } & \multicolumn{3}{c|}{ ACC (3) } & \multicolumn{3}{c|}{ ACH (3) } \\
\hline & OBL & INC & OP & OBL & INC & OP & OBL & INC & OP \\
\hline $2^{\text {nd }}$ Year & $27 \%$ & $37 \%$ & $36 \%$ & $41.67 \%$ & $31.67 \%$ & $26.67 \%$ & $11.67 \%$ & $46.67 \%$ & $41.67 \%$ \\
\hline $3^{\text {rd }}$ Year & $38 \%$ & $29 \%$ & $33 \%$ & $28.33 \%$ & $30 \%$ & $41.67 \%$ & $26.67 \%$ & $33.33 \%$ & $40 \%$ \\
\hline NS & $20 \%$ & $21 \%$ & $59 \%$ & $43.33 \%$ & $46.67 \%$ & $76.67 \%$ & $20 \%$ & $15 \%$ & $65 \%$ \\
\hline
\end{tabular}

\subsubsection{Results for perfective -Le in Optional Contexts}

For perfective -le in optional contexts, data from the NS group showed that they judged -le as optional in more than half of the optional contexts (59\% with STA, 71\% with ACT, 70\% with ACC, and 62.55\% with ACH; see Table 11). Both the second-year learners and the third-year learners judged -le as obligatory with 45\% of the ACC. However, the third-year learners judged le as obligatory with $66.67 \%$ of the $\mathrm{ACH}$, while the percentage from the second-year learners was $47.5 \%$. It showed that the third-year learners use perfective -le in a more prototypical way than the second-year learners, which did not confirm the Developmental Prediction of the AH. In addition, the second-year learners judged -le as obligatory with 39\% of STA, which was higher than that with ACT (24\%). This did not support the Association Prediction of the AH, which 
predicts that the association between perfective aspect marker with ACT should be stronger than the association between perfective aspect marker with STA.

Table 11: Percentage of the Judgments of Optional -Le in Optional Contexts

\begin{tabular}{|c|c|c|c|c|c|c|}
\hline Tokens & \multicolumn{3}{|c|}{ STA (5) } & \multicolumn{3}{c|}{ ACT (5) } \\
\hline & OBL & INC & OP & OBL & INC & OP \\
\hline $\mathbf{2}^{\text {nd }}$ Year & $39 \%$ & $40 \%$ & $21 \%$ & $24 \%$ & $39 \%$ & $37 \%$ \\
\hline $\mathbf{3}^{\text {rd }}$ Year & $40 \%$ & $26 \%$ & $34 \%$ & $25 \%$ & $22 \%$ & $53 \%$ \\
\hline NS & $20 \%$ & $21 \%$ & $59 \%$ & $14 \%$ & $15 \%$ & $71 \%$ \\
\hline Tokens & \multicolumn{3}{|c|}{ ACC (4) } & & & ACH (6) \\
\hline & OBL & INC & OP & OBL & INC & OP \\
\hline $\mathbf{2}^{\text {nd }}$ Year & $45 \%$ & $38.75 \%$ & $16.25 \%$ & $47.50 \%$ & $27.50 \%$ & $25 \%$ \\
\hline $\mathbf{3}^{\text {rd }}$ Year & $45 \%$ & $18.75 \%$ & $36.25 \%$ & $66.67 \%$ & $18.33 \%$ & $15 \%$ \\
\hline NS & $16.25 \%$ & $13.75 \%$ & $70 \%$ & $20 \%$ & $17.50 \%$ & $62.50 \%$ \\
\hline
\end{tabular}

\subsection{DISCUSSION}

\subsubsection{The Default Past Tense Hypothesis}

The current study uses learners' judgments in context partly because previous research studying 
L2 English acquisition has shown that both the Association Prediction and Developmental Prediction of the AH are supported by paper-and-pencil test. In paper-and-pencil tests, learners focus less on meaning but more on form. Therefore, the results may reflect the learners' semantic representations of tense-aspect morphology more directly (Shirai, 2004). However, the present study found that learners' judgments on obligatory -le in obligatory contexts does not support the Developmental Prediction of the Aspect Hypothesis. The results instead are consistent with the Default Past Tense Hypothesis (DPTH). The DPTH has been tested and verified in beginning level learners of Spanish with L1 English (Salaberry, 1999, 2003, 2011). It predicts that learners initially use perfective past marking as a default past tense marker. If translated into the acquisition of Chinese, it predicts that learners will use perfective aspect marker -le as a past tense marker by default; hence the use of perfective -le will be less restricted by the inherent aspectual meaning at an initial stage; as learners' proficiency goes up, it will become more restricted by the inherent aspectual meaning of the predicates. After learners reach an advanced level, they will be less affected by the inherent aspectual meaning again and become more native-like.

\subsubsection{The Judgments of Obligatory Zai with ACC and ACH in Obligatory Contexts}

It is very interesting that in obligatory zai context, the third-year learners of Mandarin Chinese associated progressive zai much more strongly with ACH (65\%) than with ACC (38.75\%) in obligatory contexts (see Table 6). Second-year learners of Mandarin Chinese showed the same pattern (46.25\% v.s. $37.5 \%)$ in the same context. A detailed look at these sentences is included in Table 12.

With the four ACC, $60 \%$ of the third-year learners chose zai as obligatory with shang louti 
'to go upstairs' and 50\% of them choose obligatory zai with mai 'to sell'. On the contrary, the percentage for the other two (mai 'to buy' and zouchu 'to go out of') were very low (25\% and $20 \%$, respectively). The reasons for why the participants do not choose obligatory zai for them are not very clear, but there are some possible explanations.

The sentence in (14) had a low acceptance rate (25\%):

\section{(14) 小李现在肯定 $[$ ]买啤酒，因为晚上他要开一个party。}

xiaoli xianzai kending [] mai pijiu, yinwei wanshang ta yao kai yige party

I'm sure that Little Li is [ ] buying beer now, because he is having a party tonight.

The sentence with mai ‘to buy' (sentence (14)) is relatively more complex than other sentences. All other sentences in Table 12 concerns direct descriptions of on-going events, but in this sentence, the progressiveness is invisible, i.e. the speaker is guessing what the person must be doing now (buying beer) by referring to another planned activity (the party tonight). Therefore, the participants need to cognitively process the progressiveness of the event (buying beer) through inferencing, which may be a failure for most of the participants under the condition of doing experimental tests. In other words, this is not a basic, prototypical use of progressive zai.

The sentences with zouchu 'go out of' were not judged as obligatory at a high percentage either by the second-year learners (30\% of second-year learners chose zai as obligatory in this context). For the predicate zouchu 'go out of', there can be two different interpretations. First, chu 'out' can be a direction of the action zou 'walk/go'. In this case, zouchu 'go out of' is compatible with progressive zai. Second, chu 'out' can be a result of the action zou 'walk/go'. In this case, zouchu 'go out of' is a RVC, which is not compatible with progressive zai. The sentence in the judgment test (sentence (15)) avoids the second option (zouchu is RVC) by adding a context in the first half of the sentence: wo gang xiake 'the class was just over'. Hence 
all native speakers (100\%) chose zai as obligatory in this context. However, it may be difficult for L2 learners to process the differences. It is also possible that the participants did not pay attention to the first half of the sentence, but only focused on the second half with the blank.

\section{(15) 我刚下课，我[ ]走出教室。}

wo gang xiake, wo [ ] zouchu jiaoshi

The class is just over; I am [ ] going out of the classroom.

In addition, many third-year learners chose obligatory zai with all four items in the obligatory context $(60 \%, 65 \%, 70 \%$, and $65 \%$, respectively, for each item). One possible reason is that the third-year learners were becoming more native-like. Another possible reason is that among the four items in this category, two items (dagu 'to play the drum' and sa 'to spill') are not prototypical ACH, but semelfactive verbs. Semelfative verbs (Li, 1990) are strongly associated with the progressive universally (e.g., Li \& Shirai, 2000; Andersen \& Shirai, 1995). Only a few prototypical ACH, however, are compatible with progressive zai (e.g., Jin \& Hendriks, 1997). Therefore, it is very hard to avoid semelfactive verbs at all in the tests.

Most participants reported that they learned progressive zai in their first year of learning Chinese, and after that zai was never emphasized and rarely practiced. Therefore, most of them felt that the test for zai was much harder than the test for -le, and they were not sure about their answers for zai when doing the judgment test. However, because perfective -le is a very difficult point in Chinese language teaching and learning, it is practiced frequently in classes. Both students and instructors put great emphasis on it. That can be one reason why the third-year students used -le with each category of verbs very evenly, just as the native speakers did, but not zai.

From a pedagogical perspective, the results show that progressive zai is much easier than 
perfective -le to acquire. However, instructors still need to emphasize more on the progressive zai and have students exposed more to it.

Table 12: Percentage of the Participants Who Judged Zai as Obligatory with Telic Verbs in Obligatory Contexts

\begin{tabular}{|c|c|c|c|c|c|}
\hline \multirow[t]{2}{*}{ Category } & \multirow[t]{2}{*}{$\begin{array}{l}\text { Verb } \\
\text { Tested }\end{array}$} & \multirow[t]{2}{*}{ Sentence Used } & \multicolumn{3}{|c|}{$\begin{array}{l}\text { Percentage of } \\
\text { participants who } \\
\text { judged OBL zai }\end{array}$} \\
\hline & & & $2^{\text {nd }}$ & $3^{\text {rd }}$ & NS \\
\hline \multirow{4}{*}{ ACC } & $\begin{array}{l}\text { shang louti } \\
\text { 'to go } \\
\text { upstairs' }\end{array}$ & $\begin{array}{l}\text { (13)你看，那个小孩 [ ]上楼梯。 } \\
\text { 'Look, the little kid is [ ] going upstairs.' }\end{array}$ & $35 \%$ & $60 \%$ & $90 \%$ \\
\hline & mai 'to buy' & $\begin{array}{l}\text { (14)小李现在肯定[ ]买啤酒, 因为晚 } \\
\text { 上他要开一个party。 } \\
\text { 'I'm sure that Little Li is [ ] buying beer } \\
\text { now, because he is having a party } \\
\text { tonight.' }\end{array}$ & $30 \%$ & $25 \%$ & $95 \%$ \\
\hline & $\begin{array}{l}\text { zouchu 'to } \\
\text { go out of' }\end{array}$ & $\begin{array}{l}\text { (15)我刚下课，我[ ]走出教室。 } \\
\text { 'The class is just over. I am [ ] going out } \\
\text { of the classroom.' }\end{array}$ & $30 \%$ & $20 \%$ & $100 \%$ \\
\hline & mai 'to sell' & $\begin{array}{l}\text { (16)今天商店[ ]卖便宜的水果。 } \\
\text { 'Today the store is [ ] selling cheap } \\
\text { fruits.' }\end{array}$ & $55 \%$ & $50 \%$ & $95 \%$ \\
\hline \multirow[b]{2}{*}{ ACH } & $\begin{array}{l}\text { qifei '(plane) } \\
\text { take off' }\end{array}$ & $\begin{array}{l}\text { (17)飞机[ ]起飞, 你看见外面的房子 } \\
\text { 在动了吗 ? } \\
\text { 'The plane is [ ] taking off. Did you see } \\
\text { the building moving outside?' }\end{array}$ & $45 \%$ & $60 \%$ & $90 \%$ \\
\hline & $\begin{array}{l}\text { dagu 'to } \\
\text { play the } \\
\text { drum' }\end{array}$ & $\begin{array}{l}\text { (18)刚才我 [ ]打鼓, 没有听见电话 } \\
\text { 响。 } \\
\text { 'I was [ ] playing the drum, so I didn't } \\
\text { hear my phone ringing.' }\end{array}$ & $55 \%$ & $65 \%$ & $100 \%$ \\
\hline
\end{tabular}




\begin{tabular}{|l|l|l|l|l|l|}
\hline sa 'to spill' & $\begin{array}{l}\text { (19)小王[ ]酒水 , 小心别被弄湿了。 } \\
\text { 'Little Wang is [ ] spilling water onto } \\
\text { the ground. Be careful not to get wet.' }\end{array}$ & $40 \%$ & $70 \%$ & $95 \%$ \\
\cline { 2 - 6 } & $\begin{array}{l}\text { reng 'to } \\
\text { throw away' }\end{array}$ & $\begin{array}{l}\text { (20)我去小王家的时候 , 他 [ ]扔垃 } \\
\text { 圾。 } \\
\text { 'When I went to Little Wang's place, he } \\
\text { was [ ] throwing away garbage.' }\end{array}$ & $45 \%$ & $65 \%$ & $100 \%$ \\
\hline
\end{tabular}

\subsubsection{The Judgments of Obligatory -Le with ACT and ACC in Obligatory Contexts}

Second-year learners associated perfective -le more strongly with ACT (60\%) than with ACC (43.8\%), which is against the prediction of the AH (see Table 7). Third-year learners showed the same pattern as well, though the difference was much smaller (62\% v.s. 67.5\%). Let’s look at the tested sentences in details. The tested verbs are listed in detail in Table 13.

Sentences (22), (23), (24), and (26) have past time adverbials in each of them, such as yesterday, last weekend, and yesterday afternoon. The percentages of second-year leaners who judged -le as obligatory are all very high in these sentences $(75 \%, 55 \%, 60 \%$, and $90 \%$, respectively), but in other sentences where there was no past tense adverbial, the percentages were relatively low. In contrast, third-year learners were able to judge -le as obligatory at a high percentage in sentences without past tense adverbial (e.g., sentences (15) and (19)). It is possible that lower-level learners use perfective -le as a past tense marker regardless of the inherent aspectual value of the verb predicates, while higher-level learners tend to regard -le as perfective aspect marker and use it in a way more restricted by the inherent aspectual meanings. 
Table 13: Percentage of the Participants Who Judged -Le as Obligatory with ACT and ACC in Obligatory Contexts

\begin{tabular}{|c|c|c|c|c|c|}
\hline \multirow[t]{2}{*}{ Category } & \multirow[t]{2}{*}{$\begin{array}{l}\text { Verb } \\
\text { Tested }\end{array}$} & \multirow[t]{2}{*}{ Sentence Used } & \multicolumn{3}{|c|}{$\begin{array}{l}\text { Percentage of } \\
\text { participants who } \\
\text { judged OBL -le }\end{array}$} \\
\hline & & & $2^{\text {nd }}$ & $3^{\text {rd }}$ & NS \\
\hline \multirow{4}{*}{ ACT } & $\begin{array}{l}\text { gongzuo } \\
\text { 'to work' }\end{array}$ & $\begin{array}{l}\text { (21)小王在这里工作[ ]二十年。 } \\
\text { 'Little Wang worked [ ] here for } 20 \\
\text { years.' }\end{array}$ & $50 \%$ & $60 \%$ & $100 \%$ \\
\hline & chi 'to eat' & $\begin{array}{l}\text { (22)我昨天只吃[ ]一顿饭, 因为我没钱 } \\
\text { 了。 } \\
\text { 'I only ate [ ] one meal yesterday, because } \\
\text { I didn't have money.' }\end{array}$ & $75 \%$ & $100 \%$ & $100 \%$ \\
\hline & $\begin{array}{l}\text { kan 'to } \\
\text { watch' }\end{array}$ & $\begin{array}{l}\text { (23)上个周末我跟我的中国朋友一起看 } \\
\text { [ ]中国电影, 很有意思。 } \\
\text { 'I watched [ ] a Chinese movie with my } \\
\text { friends last weekend, and it was very } \\
\text { interesting.' }\end{array}$ & $55 \%$ & $60 \%$ & $95 \%$ \\
\hline & $\begin{array}{l}\text { youyong } \\
\text { 'to swim' }\end{array}$ & $\begin{array}{l}\text { (24)我昨天和朋友一起游泳 [ ]。 } \\
\text { 'Yesterday, I swam [ ] with my friends.' }\end{array}$ & $60 \%$ & $50 \%$ & $100 \%$ \\
\hline & $\begin{array}{l}\text { Xie } 20 \text { ge } \\
z i \text { 'to write } \\
20 \\
\text { Chinese } \\
\text { characters' }\end{array}$ & $\begin{array}{l}\text { (25)小王十分钟之内写 [ ]20个字。 } \\
\text { 'Little Wang write [ ] } 20 \text { Chinese } \\
\text { characters in ten minutes.' }\end{array}$ & $35 \%$ & $80 \%$ & $100 \%$ \\
\hline & $\begin{array}{l}\text { mai 'to } \\
\text { buy' }\end{array}$ & (26)小王昨天下午去商店买 [ ]很多圣诞 & & & \\
\hline
\end{tabular}




\begin{tabular}{|c|l|l|l|l|l|}
\hline ACC & $\begin{array}{l}\text { 礼物。 } \\
\text { 'Yesterday afternoon Little Wang went to } \\
\text { the store and bought [ ] many Christmas } \\
\text { gifts.' }\end{array}$ & $90 \%$ & $80 \%$ & $100 \%$ \\
\cline { 2 - 6 } & $\begin{array}{l}\text { paojin 'to } \\
\text { run into' }\end{array}$ & $\begin{array}{l}\text { (27)我看见那只兔子跑进[ ]小房子。 } \\
\text { 'I saw the rabbit run into [ ] the little } \\
\text { house.' }\end{array}$ & $30 \%$ & $40 \%$ & $95 \%$ \\
\cline { 2 - 6 } & $\begin{array}{l}\text { shanglou } \\
\text { 'to go } \\
\text { upstaires' }\end{array}$ & $\begin{array}{l}\text { (28)妈妈一个小时之前上楼 [ ] , 你可以 } \\
\text { 去楼上找她。 } \\
\text { 'Mom went upstairs [ ] an hour ago, you } \\
\text { can go upstairs to see her.' }\end{array}$ & $35 \%$ & $50 \%$ & $100 \%$ \\
\hline
\end{tabular}

\subsubsection{The Extension of the DPTH}

The Default Past Tense Hypothesis has been supported in L2 acquisition of Spanish (Salaberry, 1999; 2003; 2011) and Russian (Martelle, 2011) by English-L1 learners. Salaberry (1999) found that L2 Spanish learners use past tense Spanish preterite acts as a default marker of past tense during the beginning stages of acquisition. Martelle (2011) found that the beginning-level learners of Russian initially used the imperfective past marker as their default past tense marker. The present study also found that L2 learners of Mandarin Chinese use perfective aspect marker -le as their default past tense marker at a lower proficiency level. For these L2 learners, they are not sensitive to the interaction with lexical aspect and grammatical aspect, and they are less restricted by the inherent lexical aspect at the initial stages of their learning.

Moreover, although the DPTH has only been examined within the context of past tense so far, the same pattern was shown in L2 acquisition of Mandarin Chinese progressive aspect marker zai as well in this study (see Table 14).

Table 14: Percentage of the Judgments of Obligatory Zai in Obligatory Contexts 


\begin{tabular}{|c|c|c|c|}
\hline Tokens & ACT (5) & ACC (4) & ACH (4) \\
\hline $\mathbf{2}^{\text {nd }}$ Year & $63 \%$ & $37.5 \%$ & $46.25 \%$ \\
\hline $\mathbf{3}^{\text {rd }}$ Year & $73 \%$ & $38.75 \%$ & $65 \%$ \\
\hline
\end{tabular}

The Developmental Prediction ${ }^{3}$ is not supported because third-year learners associate zai with ACT (73\%) more strongly than second-year learners (63\%). Compared to third-year learners, second-year learners do not differentiate different lexical aspect categories of the predicates to a large degree. Within the categories of ACC and ACH (see Table 15), second-year learners chose obligatory zai with each verb more evenly (ranging from 30\% to 55\%), regardless of the lexical category. However, third-year learners' choices vary a lot (ranging from 20\% to 70\%). It may suggest that second-year learners (learners at beginning stages) are less sensitive to the interaction of lexical aspect and grammatical aspect. Moreover, third-year students accept the prototypical ACT with zai more frequently than second-year students. In the rejections of zai in incorrect contexts, results show that third-year learners reject zai with prototypical uses (i.e., with ACT and ACC) less, even in incorrect contexts, which means that third-year learners are more comfortable with these prototypical uses of zai. These observations go along with the predictions of DPTH in the sense that learners are more sensitive at the intermediate level, rather than beginning level to lexical aspect. Because we are talking not about past tense but progressive tense, the Default Past Tense Hypothesis needs to be extended from past tense to progressive tense. It can be concluded that L2 learners of Mandarin Chinese at initial stages use progressive marker zai regardless the lexical aspect of the predicates. Together with the results of

3 Second-year learners associate zai with ACC (37.5\%) less strongly than with ACH (46.25\%), which is also against the Association Prediction. Third-year learners show the same patterns. This in fact is probably an artifact of item choice, as discussed above. 
perfective marker -le, we can hypothesize that $\mathrm{L} 2$ learners at the beginning stages are insensitive to lexical aspect, and they use aspect markers as default tense markers. This can be labeled as the Lexical Insensitivity Hypothesis (LIH), which predicts that:

Lexical Insensitivity Hypothesis: learners at the beginning stages are insensitive to lexical aspect, but as the learners' proficiency goes up, they become more sensitive to lexical aspect, and thus become more restricted by the inherent aspectual meanings of the predicates when producing aspect markers.

Table 15: The Percentage of Participants Who Judged Obligatory Zai with Telic Verbs in Obligatory Contexts

\begin{tabular}{|c|l|c|c|c|}
\hline \multirow{4}{*}{ Category } & \multicolumn{2}{|c|}{ Verb Tested } & \multicolumn{3}{|c|}{$\begin{array}{c}\text { Percentage of participants } \\
\text { who judged obligatory zai }\end{array}$} \\
\cline { 3 - 5 } & & $\mathbf{2}^{\text {nd }}$ & $\mathbf{3}^{\text {rd }}$ & NS \\
\hline \multirow{4}{*}{ ACC } & Shang louti ‘to go upstairs' & $35 \%$ & $60 \%$ & $90 \%$ \\
\cline { 2 - 5 } & mai ‘to buy' & $30 \%$ & $25 \%$ & $95 \%$ \\
\cline { 2 - 5 } & zouchu 'to go out of' & $30 \%$ & $20 \%$ & $100 \%$ \\
\cline { 2 - 5 } & mai 'to sell' & $55 \%$ & $50 \%$ & $95 \%$ \\
\hline \multirow{4}{*}{ ACH } & qifei ‘(plane) take off' & $45 \%$ & $60 \%$ & $90 \%$ \\
\cline { 2 - 5 } & dagu 'to play the drum' & $55 \%$ & $65 \%$ & $100 \%$ \\
\cline { 2 - 5 } & sa 'to spill' & $40 \%$ & $70 \%$ & $95 \%$ \\
\cline { 2 - 5 } & reng ‘to throw away' & $45 \%$ & $65 \%$ & $100 \%$ \\
\hline
\end{tabular}

Most of the studies supporting the DPTH are tested among L1 English speakers learning an L2, and most of the tasks used are eliciting a controlled production. The LIH is based on the 
present study, which also investigated L1 English speakers learning L2 Mandarin and elicited controlled data. However, the Aspect Hypothesis, which predicts that L2 learners are initially more restricted by lexical aspect, is supported by studies on different L1 speakers learning an L2 with both control productions and free productions. Therefore, different L1s and the tasks are possible explanations for the different patterns in L2 acquisition predicted by different hypotheses. Moreover, because English is a language with a highly developed past tense system and a developed progressive tense system as well, it can be an important effect for learners of L1 English when learning an L2. Both the DPTH and the LIH need to be tested with learners of different L1s learning other languages in future research. 


\subsection{CONCLUSION}

First, in the present study, data from both second-year learners and third-year learners of Mandarin Chinese partially supported the Association Prediction of the Aspect Hypothesis in the acquisition of progressive aspect marker zai in obligatory contexts, but not in incorrect contexts and optional contexts. The Developmental Prediction of the Aspect Hypothesis was not supported in any of the three contexts. Results show that third-year learners use progressive zai more prototypically.

Second, the results in all three contexts (OBL, INC, and OP) from neither second-year learners nor third-year learners supported the Association Prediction in the acquisition of perfective aspect marker -le. The results do not support the Developmental Prediction, either. The Default Past Tense Hypothesis has been supported by the results, which means that in L2 acquisition of Mandarin Chinese, learners initially use perfective aspect marker -le as a default past tense marker. Thus, lower-level learners use perfective -le less restricted by the inherent aspectual meaning than higher-level learners. Although previous research (e.g., Andersen, 1991) shows that in L2 acquisition of tense-aspect, when learners' L1 is English, both the Association Prediction and the Developmental Prediction would be supported, the current study does not follow the pattern.

The Default Past Tense Hypothesis has been supported and extended from past tense to progressive aspect. The Lexical Insensitivity Hypothesis has been proposed. It predicts that L2 
learners at beginning stages are insensitive to lexical aspect; hence they use aspect markers as default tense markers. As the learners' proficiency goes up, they become more sensitive to lexical aspect, and they produce aspect markers in a way more restricted by the lexical aspectual meanings of the predicates. It is suggested that the LIH is supported under the condition of learners of L1 English learning an L2 in a classroom setting. 


\subsection{FUTURE RESEARCH}

In future research, a more balanced test should be designed to make the number of tokens of predicates in each category and each context even. Also, it might be better to use both free production data and controlled production data to test the Aspect Hypothesis, the Default Past Tense Hypothesis, and the Lexical Insensitivity Hypothesis. Moreover, since the DPTH has only been tested with L1 English speakers only, it is a good idea to test it with speakers from other L1s.

Although all the tested predicate items were carefully examined with operational tests for the aspectual categories of predicates, there were still a few ambiguous ones, including two semelfactive verbs. In future studies, these items should be completely avoided.

In the study, heritage learners and non-heritage learners are not distinguished. There might be different patterns between heritage learners and non-heritage learners, although in Korean the Aspect Hypothesis is supported by the data from heritage learners of L2 Korean (Lee \& Kim, 2007). Future research can compare the two groups to test possible differences. 


\section{APPENDIX A}

\section{OPERATIONAL TESTS FOR THE ASPECTUAL CATEGORIES OF PREDICATES}

Predicates are indicated in bold italics.

\section{Step 1: State or non-state (non-dynamic vs. dynamic)}

Can the verb (or verb phrase) cannot have a habitual interpretation without any aspect marker attached?

If it cannot $\rightarrow$ state (e.g., Wo ai ni "I love you” $\rightarrow$ no habitual reading)

If it can $\rightarrow$ non-state (e.g., Wo tiantian chi mifan "I every day eat rice” (I eat rice every day) $\rightarrow$ habitual reading possible) $\rightarrow$ Go to Step 2

\section{Step 2: Punctual or durative}

[If test (a) does not apply, apply test (b)]

(a) Can you say "X kai shi VP” (= "X begin to VP”) without an iterative interpretation?

If you cannot $\rightarrow$ Achievement (e.g., \#Ta kaishi si "he begins to die”)

If you can $\rightarrow$ Accomplishment (e.g., Ta kaishi xie yi feng xin "he begins to write a letter”) or Activity (e.g., Ta kaishi paobu "he begins to run”) $\rightarrow$ Go to Step 3

(b) Can you say “ X will VP at Y o’clock (e.g., 2 o’clock) sharp”?

If you can $\rightarrow$ Achievement (e.g., Huiyi hui zai 2 dian zheng kaishi "Lit: meeting will at 2 
o'clock sharp begin” (The meeting will begin at 2 o'clock sharp) $\rightarrow$ achievement If you cannot $\rightarrow$ Accomplishment or Activity $\rightarrow$ Go to Step 3

\section{Step 3: Accomplishment or Activity (Telic vs. atelic)}

[If test (a) does not apply, apply test (b)]

(a) Can "X chadianr VP le" (= "X almost VP le") mean "X started V but did not complete it”?

If it can $\rightarrow$ Accomplishment (e.g., Ta chadianr paodao xuexiao le "Lit: he almost run arrive school le" (he almost ran to the school), can mean that he started running but he didn’t reach the school)

If it cannot $\rightarrow$ Activity (e.g., Ta chadianr pao le bu "he almost ran le" (he almost ran) can only be interpreted as he almost started running)

(b) Can you say "X will VP for Y time” (e.g., 10 minutes)?

If you can $\rightarrow$ Activity (e.g., Ta hui zuo 10 fenzhong "he will sit for 10 minutes”).

If you cannot $\rightarrow$ Accomplishment (e.g., \#Ta pao dao xuexiao 10 fenzhong "he run arrive school 10 minutes” (\#He ran to school for 10 minutes)

(Chen \& Shirai, 2010) ${ }^{4}$

\footnotetext{
${ }^{4}$ Because achievement verbs and semelfactive verbs were not distinguished here, Step 4 (the step distinguishes achievement verbs and semelfactives) from the version of Chen \& Shirai was omitted.
} 


\section{APPENDIX B}

\section{JUDGMENT TEST -- “在”}

Note:

1. The designed answers are given in the Appendix but not in the test paper given to the participants.

2. The tested verbs are underlined and the categories are given in the Appendix but not shown to the participants.

3. Answers and the categories of predicates are shown here but not to the participants.

Date:

Participant \#

Instruction: Write “在” where you think is necessary; Put “ $\varnothing$ ” in the brackets if you think the use of “在” is incorrect; Write “OP” if you think “在” is optional.

\section{1) Sentences}

1. 他昨天一个下午都 [ Ø] 坐在椅子上。(STA)

2. 我 $[\mathrm{OP}]$ 上楼。(ACC)

3. 她 [ 在 ] 读书, 我们不要打扰她。(ACT)

4. 我刚下课, 我 [ 在 ] 走出教室。(ACC)

5. 小王在那儿, [ Ø ] 站在桌子上。(STA)

6. 小送了我一本中文书, 我 [ Ø ] 有中文书了。(STA)

7. 没有空气, 人不能 $[\varnothing]$ 存在。(STA)

8. 我 [ Ø] 知道明天要考试, 小王已经告诉我了。(STA)

9. 飞机 [ 在 ] 起飞, 你看见外面的房子在动了吗 ? (ACH)

10. 我去小王家的时候, 他 [ 在 ] 扔垃圾。 $(\mathrm{ACH})$ 
11. 你什么时候 [ Ø] 到学校 ? (ACH)

12. 大家都 [ 在 ] 走出教室。(ACC)

13. 我在中国 [ Ø ] 工作。(ACT)

14. 她长得 [ Ø] 像她的妈妈。(STA)

15. 我现在 [ Ø]焦在公寓。(STA)

16. 刚才我 [ 在 ] 打鼓, 没有听见电话响。(ACH)

17. 我以前喜欢中国菜, 可是我现在 [ Ø ] 喜欢美国菜。(STA)

18. 我哥哥以前 [ Ø ] 是一个医生。(STA)

19. 我 [ Ø] 觉得这个电影很没有意思。(STA)

20. 昨天小王给我打电话的时候我 [ 在 ] 工作。(ACT)

21. 今天早上 8 点的时候我 [ 在 ] 吃早饭。(ACT)

22. 小王 [ Ø] 矢我一百块钱。(STA)

23. 小王 [ 在 ] 游泳, 你们等会儿再来找他吧。(ACT)

24. 一他做什么呢? - 他 [ OP ] 游泳呢。(ACT)

25. 小李现在肯定 [ 在 ] 买啤酒, 因为晚上他要开一个party。(ACC)

26. 我现在 [ OP ] 跑马拉松 (Marathon)。(ACT)

27. 我 [ Ø] 吃晚饭的时候已经 9 点了。(ACT)

28. 刚才 [ OP ] 划船的时候, 我看见水里有很多鱼。(ACT)

29. 今天商店 [ 在 ] 卖便宜的水果。(ACC)

30. 昨晚我 [ Ø ] 睡了10个小时。(ACT)

31. 足球比赛我们 [ Ø ] 输了很多次。 $(\mathrm{ACH})$

32. 我 [ OP ] 扔球给他。(ACH)

33. 电影 [ Ø] 开始了, 请你安静一下。(ACH)

34. 这家商店常常 [ Ø] 卖又好看又便宜的衣服。(ACC)

35. 小王 [ 在 ] 酒水，小心别被弄湿了。(ACH)

36. 我们的足球队 [ Ø ] 赢了那场比赛。( $\mathrm{ACH})$

37. 我 [ OP ] 问老师问题。(ACH)

38. 你看, 那个小孩 [ 在 ] 上楼梯。(ACC)

39. 昨天小王 [ OP ] 买衣服的时候试了很久。(ACC)

40. 我 [ OP ] 走出教室, 正好看见了他。(ACC) 
41. 昨天下午小王 [ Ø ] 买了一件衣服。(ACC)

42. 下雨了, 大家都 [ Ø ] 跑进房子里去了。(ACC)

\section{2) Paragraph:}

我 43.[Ø]焦(STA)在上海。昨天小李来找我的时候我 44.[在]工作(ACT)。他问我 45.[Ø]坐火车 $(\mathrm{ACH})$ 去旅行怎么样。我 46.[Ø]停 $(\mathrm{ACH})$ 下工作和他商量了一会儿, 就决定 和他一起去北京。47.[Ø]去(ACH)北京的火车上我一直 48.[OP] 睡(ACT), 因为从上海到北 京坐火车要 10 个小时, 而且是晚上。我 49.[Ø]知道(STA)北京的长城很有意思, 所以 50.[Ø]到(ACH)北京的第一天我们就去了长城。接下来的两天我们还 51.[Ø]到(ACH)了北 京的很多地方, 我们都觉得很有意思。三天以后我们回上海。52.[OP] 旅行(ACT)的时候我 53.[Ø]有(STA)了一个想法, 那就是工作再忙也要花时间去旅行, 因为旅行能让人快乐。

English Translation (not shown to the participants):

Date: Participant \#

Instruction: Write "ZAI" where you think is necessary; Put " $\varnothing$ " in the brackets if you think the use of "ZAI" is incorrect; Write "OP" if you think "ZAI" is optional.

\section{Sentences}

1. He $[\varnothing]$ sat in the chair for the whole afternoon yesterday. (STA)

2. I am [OP] going upstairs. (ACC)

3. She is [ZAI] reading. We shouldn't bother her. (ACT)

4. The class is just over. I am [ZAI] getting out of the classroom. (ACC)

5 . Little Wang is over there, $[\varnothing]$ standing on the desk. (STA)

6. Little Wang gave me a Chinese book. I now [Ø] have a Chinese book. (STA)

7. Without air humans cannot [Ø] exist. (STA)

8. I [Ø] know that there's a test tomorrow, because Little Li told me already. (STA)

9. The plane is [ZAI] taking off. Did you see the building moving outside? (ACH)

10. When I went to Little Wang's place, he was [ZAI] throwing garbage. (ACH)

11. When will you $[\varnothing]$ arrive at school? (ACH)

12. Everyone is [ZAI] getting out of the classroom. (ACC) 
13. I [Ø] work in China. (ACT)

14. She $[\varnothing]$ resembles her mother in appearance. (STA)

15. I now [Ø] live in an apartment. (STA)

16. I was [ZAI] playing the drum, so I didn't hear my phone ringing. (ACH)

17. I liked Chinese food before, but now I [Ø] like American food. (STA)

18. My brother $[\varnothing]$ was a doctor before. (STA)

19. I [Ø] feel the movie is not interesting. (STA)

20. When Little Li called me yesterday, I was [ZAI] working. (ACT)

21. I was [ZAI] eating breakfast at 8 o'clock this morning. (ACT)

22. Little Wang [Ø] owed me 100 dollars. (STA)

23. Little Wang is [ZAI] swimming. You can come to see him later. (ACT)

24. -What are you doing? - I am [OP] swimming. (ACT)

25. I'm sure that Little $\mathrm{Li}$ is [ZAI] buying beer now, because he is having a party tonight. (ACC)

26. I am [OP] running a marathon right now. (ACT)

27. It was already 9 o'clock when I [Ø] ate dinner. (ACT)

28. When we were [OP] row-boating just now, I saw lots of fishes in the water. (ACT)

29. Today the store is [ZAI] selling cheap fruits. (ACC)

30. I [Ø] slept for 10 hours last night. (ACT)

31. We [Ø] lost many times in the football games. (ACH)

32. I am [OP] throwing the ball to him. (ACH)

33. The movie $[\varnothing]$ begins. Be quiet. (ACH)

34. This store always [Ø] sells beautiful and cheap clothes. (ACC)

35. Little Wang is [ZAI] spilling water onto the ground. Be careful not to get wet. (ACH)

36. Our football team $[\varnothing]$ won that game. (ACH)

37. I am [OP] asking the teacher questions. (ACH)

38. Look, the little kid is [ZAI] going upstairs. (ACC)

39. Little Wang tried for a long time when [OP] buying these clothes. (ACC)

40. I was [OP] getting out of the classroom, and right then I saw him. (ACC)

41. Yesterday afternoon Little Wang [Ø] bought a coat. (ACC)

42. It's raining. Everyone is [Ø] running into the house. (ACC) 


\section{Paragraph:}

I 43. [Ø] live (STA) in Shanghai. I was 44. [ZAI] working (ACT) when Little Li came to see me yesterday. He asked me how about 45. [Ø] taking a train (ACH) to travel. I 46. [Ø] stopped $(\mathrm{ACH})$ working and discussed with him for a while, and then I decided to go to Beijing with him. On the train 47. [Ø] to (ACH) Beijing I was 48. [OP] sleeping (ACT) all the way, because it takes 10 hours from Shanghai to Beijing by train, and it was night. I 49. [Ø] knew (STA) that the Great Wall in Beijing was very interesting, so we went there on the first day we 50. [Ø] arrived in $(\mathrm{ACH})$ Beijing. In the following five days, we 51. [Ø] went to $(\mathrm{ACH})$ many other places in Beijing. We both thought that it was fun. While 52. [OP] traveling (ACT), I 53. [Ø] had (STA) a thought, which is that however busy your work is, you need to make time to travel, because travel makes people happy. 


\section{APPENDIX C}

\section{JUDGMENT TEST -- “了”}

Date:

Participant \#

Instruction: Write “了” where you think is necessary; Put “ $\varnothing$ ” in the brackets if you think the use of “了” is incorrect; Write “OP” if you think “了” is optional.

\section{1) Sentences}

1. 小王昨天下午去商店买 [ 了 ] 很多圣诞礼物。(ACC)

2/3. 去年我在上海住 [ 了 ] 一年, 知道 [ 了 ] 很多中国人的习惯。(STA) (STA)

4. 我来美国以前不喜欢吃美国菜, 现在喜欢 [了]。(STA)

5. 小王在这里工作 [ 了 ] 二十年。(ACT)

6. 小王喜欢 [ OP ] 小雪三年, 可是不敢告诉她。(STA)

7. 这台电脑小王送给我了, 它现在属于 [ Ø ] 我。(STA)

8. 他去年工作 $[\varnothing]$ 很努力, 可是没有升职。(ACT)

9. 我现在学 $[\varnothing]$ 法文。(ACT)

10. 现在我有 [ OP ] 车, 去哪儿都很方便。(STA)

11. 我们已经决定 [了] 暑假去上海。(ACC)

12. 他以前觉得 [ Ø] 红色不好看, 所以他不买红色的衣服。(STA) 
13. 上个学期小王学中文学得不太好, 他需要 [ Ø ]一个中国朋友帮他练习中文。 (STA)

14. 上个周末我跟我的中国朋友一起看 [ 了 ] 中国电影，很有意思。(ACT)

15. 我昨天只吃 [ 了 ] 一顿饭, 因为我没钱了。(ACT)

16. 去年小王常常赌博，穴 [了] 别人很多钱。(STA)

17. 我昨天就知道 [ OP ] 这个消息。(STA)

18. 我昨天和朋友一起游泳 [ 了]。(ACT)

19. 去年我是 [ Ø ] 高中生。(STA)

20. 上次小李穴 [ OP ] 我一百块钱, 一个月都没有还。(STA)

21. 朋友们知道我跑 [ OP ] 马拉松, 都觉得很吃惊。(ACT)

22. 早上看见王老师的时候我跟她问好 [ 了 ]。( $\mathrm{ACH})$

23. 昨天我和家人去公园游泳 [ OP ], 可是游到一半的时候下大雨了。(ACT)

24. 昨天妹妹把整瓶水都酒 [ 了 ]。(ACH)

25. 我只吃 $[\varnothing]$ 素, 所以我们点素饺子吧。(ACT)

26. 我昨天跟小王一起这街 [ OP ]，买了很多衣服。(ACT)

27. 去年暑假我去 [ 了 ] 很多国家旅行。(ACH)

28. 去年我去韩国旅行 [ OP ]，吃了很多韩国菜。(ACT)

29. 昨天她来我家的时候我在睡 [ Ø ] , 所以没有听见敲门声。(ACT)

30. 比赛昨天下午三点开始 [ OP ]。(ACH)

31. 小王想去别的城市，开始 [ Ø] 新的生活。( $\mathrm{ACH})$

32. 圣诞节小王请 [ OP ] 朋友到他家一起庆祝。(ACH)

33. 上个周末的橄榄球比赛我们赢 [ OP ]。(ACH)

34. 他昨天不小心撞倒 [ 了 ] 一把椅子。( $\mathrm{ACH})$

35. 我坐 [ Ø ] 车去纽约, 因为飞机票太贵。( $\mathrm{ACH})$

36. 这个题目我不懂，我问 [ OP ] 小李，他也不懂。(ACH)

37. 妈妈告诉我，飞机半个小时以后起飞 [ Ø ]。(ACH) 
38. 妈妈一个小时之前上楼 [了 ] , 你可以去楼上找她。(ACC)

39. 小王十分钟之内写 [ 了 ] 20个字。(ACC)

40. 昨天晚上我请 [ Ø] 我的朋友们吃饭, 很晚才回家。(ACH)

41. 老鼠跑进 [ OP ] 洞里就不见了。(ACC)

42. 我看见那只兔子跑进 [ 了 ] 小房子。(ACC)

43. 妈妈刚上楼 [ OP ] , 她一会儿就下来。(ACC)

44. 小李不喜欢出去玩, 他喜欢在家上网买 [ Ø ] 很多东西。(ACC)

45. 我昨天摸黑上楼梯 [ Ø ]，不小心摔了一跤。(ACC)

46. 小王很高兴地跑进 [ Ø ] 屋子里，拿了很多玩具。(ACC)

47. 一走出 [ Ø ] 教室, 小王就把作业忘得一干二净了。(ACC)

48. 昨天我买 [ OP ] 玫瑰花, 是为了给小王准备生日礼物。(ACC)

\section{2) Paragraph:}

去年我爸爸在中国工作(ACT)49.[Ø]，所以我跟我妈妈决定去中国旅行，这样可以看 看爸爸, 也可以看看中国人平时的生活情形。我住(STA)50.[Ø]在纽约, 所以我先从纽约 坐(ACH) 51.[Ø]火车去(ACH)52.[OP]洛杉矶的家，在那里跟我妈妈见面。然后我们一起从 洛杉矶坐上了去北京的飞机。我们在东京停(ACH)53.[了]两个小时，第二天早上九点我们 到(ACH)54.[OP]北京。一出机场, 我们就看见爸爸在出口处等我们。我很高兴, 赶快跑 (ACT)55.[OP]过去问爸爸好。爸爸问我们：“你们累不累？饿不饿？”我说：“不累也不 饿。我们在飞机上睡(ACT)56.[了]五个小时的觉, 吃得也很多。现在就想看北京！”爸爸 说：“那好，我知道(STA)57.[了]，我们走吧！”爸爸还说：“有(STA)58.[OP]你们两个在我 身边，我真高兴！”我们就一起坐爸爸的车去 $(\mathrm{ACH}) 59 .[$ 了] 旅馆。 
English Translation (not shown to the participants):

Date:

Participant \#

Instruction: Write "LE" where you think is necessary; Put " $\varnothing$ " in the brackets if you think the use of "LE" is incorrect; Write "OP” if you think "LE” is optional.

\section{Sentences}

1. Yesterday afternoon Little Wang went to the store and bought [LE] many Christmas gifts. (ACC)

2/3. Last year, I lived [LE] in Shanghai for a year, and I knew [LE] lots of Chinese people's daily life. (STA) (STA)

4. I didn't like American food before I came to America, but now I like [LE] it. (STA)

5. Little Wang worked [LE] here for 20 years. (ACT)

6. Little Wang liked [OP] Little Xue for three years, but he dared not to tell her. (STA)

7. Little Wang gave the laptop to me, so it belongs to [Ø] me now. (STA)

8. He worked [Ø] very hard, but didn’t get any promotion. (ACT) 
9. Now I study [Ø] French. (ACT)

10. Now I have $[\mathrm{OP}]$ a car, so it's convenient to go anywhere. (STA)

11. We have already decided [LE] that we'll go to Shanghai in summer. (ACC)

12. He did not feel [Ø] red looked pretty before, so he never bought red clothes. (STA)

13. Last semester Little Wang didn’t learn Chinese well. He said he needed [Ø] a Chinese friend to help him practicing Chinese. (STA)

14. I watched [LE] a Chinese movie with my friends last weekend, and it was very interesting. (ACT)

15. I only ate [LE] one meal yesterday, because I didn't have money. (ACT)

16. Last year Little Li was gambling all the time, and he owed [LE] other people lots of money. (STA)

17. I knew [OP] the news yesterday. (STA)

18. Yesterday, I swam [LE] with my friends. (ACT)

19. Last year I was [Ø] a high school student. (STA)

20. Last time Little Li owed [OP] me 100 dollars. He didn’t pay me back even after a month. (STA)

21. My friends were surprised to know that I $\underline{\operatorname{ran}}[\mathrm{OP}]$ a marathon. (ACT)

22. I said hi [LE] to Professor Wang in the morning when I saw her. (ACH)

23. Yesterday I went to the park to swim [OP] with my family, but it began to rain while we were swimming. (ACT)

24. Yesterday my little sister spilled [LE] the entire bottle of water. (ACH)

25 . I only eat $[\varnothing]$ vegetarian food, so let's order some vegetarian dumplings. (ACT)

26. I went shopping [OP] with Little Wang yesterday, and I bought a lot of clothes. (ACT)

27. I went to [LE] a lot of different countries to travel last summer. (ACH)

28. Last year I traveled [OP] to Korea, and ate a lot of Korean food. (ACT)

29. I was sleeping [Ø] yesterday when she came to my house, so I didn't hear her knocking on the door. (ACT)

30. The game began $[\mathrm{OP}]$ at 3:00 yesterday afternoon. (ACH)

31. Little Wang wanted to go to some other city and began [Ø] a new life. (ACH)

32. Little Wang invited [OP] his friends to his house to spend Christmas. (ACH) 
33. We won [OP] the football game last weekend. (ACH)

34. Yesterday he carelessly knocked down [LE] a chair. (ACH)

35. I took [Ø] a bus to New York, because flight tickets were too expensive. (ACH)

36. I didn't understand the question, and I asked [OP] Little Li, but he didn't understand either. (ACH)

37. Mom told me that the plane took off [Ø] in half an hour. (ACH)

38. Mom went upstairs [LE] an hour ago, you can go upstairs to see her. (ACC)

39. Little Wang wrote [LE] 20 characters in ten minutes. (ACC)

40. I invited [Ø] my friends to dinner last night, and I went back home very late. (ACH)

41. The rat ran into [OP] the hole and disappeared. (ACC)

42. I saw the rabbit run into [LE] the little room. (ACC)

43. Mom just went upstairs [OP]. She'll come down in a minute. (ACC)

44. Little Li does not like going out. He likes staying home and shopping [Ø] online. (ACC)

45. Yesterday I went upstairs [Ø] in the dark, and fell down carelessly. (ACC)

46. Little Wang happily ran into [Ø] the room, and got many toys. (ACC)

47. Once getting out of $[\varnothing]$ the classroom, Little Wang totally forgot about the homework. (ACC)

48. Yesterday I bought [OP] roses, because I wanted to give Little Wang birthday presents. (ACC)

\section{Paragraph:}

Last year my father worked (ACT)49. [Ø] in China, so my mother and I decided to go traveling there. We thought in this way we could see my father and also see Chinese people's daily life. I was living (STA)50. [Ø] in New York, so I first took (ACH)51. [Ø] a train from New York to (ACH)52. [OP] my home in Los Angeles, where I met my mother. Then we went from L.A. to Beijing by plane. We stopped (ACH)53. [LE] at Tokyo for two hours, and arrived (ACH)54. [OP] in Beijing at nine o'clock the next morning. As soon as we walked out of the airport, we saw my father waiting at the exit. I was very happy so I ran (ACT)55. [OP] over to ask him how 
he was immediately. My father asked us, "Are you tired? Hungry?" I said, "No, we aren’t tired or hungry! We slept (ACT)56. [LE] for five hours on the plane and we ate a lot too. What we want now is to see Beijing!" My father said, "Okay, I see (know) (STA)57. [LE]. Let's go then!" My father also said: "I’m so happy that I have (STA)58. [OP] you two to be with me.” So we all went in my father's car and went to (ACH)59. [LE] the hotel. 


\section{APPENDIX D}

\section{LANGUAGE HISTORY QUESTIONNAIRE}

(Adapted from Tokowicz et al., 2004)

$$
\text { Date _ Exp_ Participant \# }
$$

Sex: M / F Age (in years) ___ Handedness: L / R Native country

This questionnaire is designed to give us a better understanding of your experience learning languages. We ask that you be as accurate and thorough as possible when answering the following questions and thank you for your participation in this study.

1) What is your first language (i.e., language first spoken)? If more than one, please briefly describe the situations in which each language was used.

2) Which language(s) OTHER THAN CHINESE do you consider your second language? 
3) If you have ever lived in or visited a country where languages other than your native language are spoken, please indicate below the name of the country (countries), the duration of your stay in number of months, and which languages you used while you were in the country (please indicate if you were spoken to in a language other than your first language, even if you never actually spoke that language).

\begin{tabular}{|l|l|l|}
\hline Country visited & \# Months there & Language(s) used \\
\hline & & \\
\hline & & \\
\hline & & \\
\hline & & \\
\hline & & \\
\hline & & \\
\hline
\end{tabular}

4) List below, from most fluent to least fluent, all of the languages you know. Also specify the age in years at which you began to learn the language and the context in which you learned it. For example, "English, birth, home”. Include all languages to which you have been exposed, although you may never have had formal training in them and may not be able to read, speak, or write them.

Please remember to list your native language

\begin{tabular}{|c|l|l|}
\hline Language & Age BEGAN & Learning Situation \\
\hline English & & \\
\hline Chinese & & \\
\hline
\end{tabular}




\begin{tabular}{|l|l|l|}
\hline & & \\
\hline & & \\
\hline & & \\
\hline
\end{tabular}

5) How many years (months) have you studied CHINESE? Please indicate the setting(s) in which you have had experience with the language (i.e., classroom, with friends, foreign country...)

\begin{tabular}{|l|}
\hline Number of years (months): \\
\hline Setting(s): \\
\hline \\
\hline \\
\hline
\end{tabular}

6) What languages were spoken in your home while you were a child and by whom? 


\section{APPENDIX E}

\section{PROFICIENCY RATINGS}

Date: Participant \#:

Directions: Listed below are a number of “can do” statements about a person's speaking ability in Chinese. Please read each description carefully and indicate by circling the appropriate number in one of the three columns, whether you would be able - at the present time - to carry out this task "quite easily," "with some difficulty,” or "with great difficulty or not at all.”

\begin{tabular}{|l|l|c|c|c|}
\hline & \multicolumn{1}{|c|}{ Quite Easily } & $\begin{array}{c}\text { With Some } \\
\text { Difficulty }\end{array}$ & $\begin{array}{c}\text { With Great } \\
\text { Difficulty or } \\
\text { not at all }\end{array}$ \\
\hline 1. & Say the days of the week. & 3 & 2 & 1 \\
\hline 2. & Count to 10 in the language. & 3 & 2 & 1 \\
\hline 3. & Give the current date (month, day, year). & 3 & 2 & 1 \\
\hline 4. & Order a simple meal in a restaurant. & 3 & 2 & 1 \\
\hline 5. & Ask directions on the street. & 3 & 2 & 1 \\
\hline 6. & Buy clothes in a department store. & 3 & 2 & 1 \\
\hline 7. & $\begin{array}{l}\text { Introduce myself in social situations, and } \\
\text { use appropriate greetings and leave-taking } \\
\text { expressions. }\end{array}$ & 3 & 2 & 1 \\
\hline 8. & $\begin{array}{l}\text { Give simple biographical information about } \\
\text { myself (place of birth, composition of } \\
\text { family, early schooling, etc.). }\end{array}$ & 3 & 2 & 1 \\
\hline 9. & $\begin{array}{l}\text { Talk about my favorite hobby at some } \\
\text { length, using appropriate vocabulary. }\end{array}$ & 3 & 2 & 1 \\
\hline 10. & $\begin{array}{l}\text { Describe my present job, studies, or other } \\
\text { major life activities accurately and in detail. }\end{array}$ & 3 & 3 & 2 \\
\hline 11. & $\begin{array}{l}\text { Tell what I plan to be doing 5 year from } \\
\text { now, using appropriate future tenses. }\end{array}$ & 3 & 2 & 2 \\
\hline
\end{tabular}




\begin{tabular}{|c|l|c|c|c|}
\hline 12. & $\begin{array}{l}\text { Describe the U.S. education system in some } \\
\text { detail. }\end{array}$ & 3 & 2 & 1 \\
\hline 13. & $\begin{array}{l}\text { Describe the role played by Congress in the } \\
\text { U.S. government system. }\end{array}$ & 3 & 2 \\
\hline 14. & $\begin{array}{l}\text { State and support with examples and } \\
\text { reasons a position on a controversial topic } \\
\text { (for example, birth control, nuclear safety, } \\
\text { environment pollution). }\end{array}$ & 3 & 2 \\
\hline
\end{tabular}

Regardless of how well you currently speak Chinese, please answer each of the following in terms of your present level of listening comprehension in the language.

\begin{tabular}{|c|c|c|c|c|}
\hline & & Quite Easily & $\begin{array}{l}\text { With Some } \\
\text { Difficulty }\end{array}$ & $\begin{array}{l}\text { With Great } \\
\text { Difficulty or } \\
\text { not at all }\end{array}$ \\
\hline 1. & $\begin{array}{l}\text { Understand very simple statements or } \\
\text { questions in the language ("Hello", "How } \\
\text { are you?", "What is your name?", "Where } \\
\text { do you live?”, etc.). }\end{array}$ & 3 & 2 & 1 \\
\hline 2. & $\begin{array}{l}\text { In face-to-face conversation, understand a } \\
\text { native speaker who is speaking slowly and } \\
\text { carefully (i.e. deliberately adapting his or } \\
\text { her speech to suit me). }\end{array}$ & 3 & 2 & 1 \\
\hline 3. & $\begin{array}{l}\text { In face-to-face conversation with a native } \\
\text { speaker who is speaking slowly and } \\
\text { carefully to me, tell whether the speaker is } \\
\text { referring to past, present, or future events. }\end{array}$ & 3 & 2 & 1 \\
\hline 4. & $\begin{array}{l}\text { In face-to-face conversation, understand } \\
\text { native speakers who are speaking to me as } \\
\text { quickly and colloquially as they would to } \\
\text { another native speaker. }\end{array}$ & 3 & 2 & 1 \\
\hline 5. & $\begin{array}{l}\text { On the telephone, understand a native } \\
\text { speaker who is speaking to me slowly and } \\
\text { carefully (i.e. deliberately adapting his or } \\
\text { her speech to suit me). }\end{array}$ & 3 & 2 & 1 \\
\hline 6. & $\begin{array}{l}\text { On the telephone, understand a native } \\
\text { speaker who is talking as quickly and as } \\
\text { colloquially as he or she would to a native } \\
\text { speaker of the language. }\end{array}$ & 3 & 2 & 1 \\
\hline 7. & $\begin{array}{l}\text { Understand two native speakers when they } \\
\text { are talking rapidly with one another. }\end{array}$ & 3 & 2 & 1 \\
\hline 8. & Understand movies without subtitles. & 3 & 2 & 1 \\
\hline 9. & Understand news broadcasts on the radio. & 3 & 2 & 1 \\
\hline 10. & Understand train departure announcements & 3 & 2 & 1 \\
\hline
\end{tabular}




\begin{tabular}{|c|l|c|c|c|}
\hline & $\begin{array}{l}\text { and similar kinds of "public address } \\
\text { system" announcements. }\end{array}$ & & \\
\hline 11. & $\begin{array}{l}\text { Understand the words of popular songs on } \\
\text { the radio. }\end{array}$ & 3 & 2 & 1 \\
\hline 12. & $\begin{array}{l}\text { Understand play-by-play descriptions of } \\
\text { sports events. }\end{array}$ & 3 & 2 & 1 \\
\hline
\end{tabular}




\section{REFERENCES}

Andersen, R. W. (1991). Developmental sequences: The emergence of aspect marking in second language acquisition. In T. Huebner \& C. A. Ferguson (Eds.), Crosscurrents in second language acquisition and linguistic theories (pp. 305-324). Amsterdam: John Benjamins.

Andersen, R. W., \& Shirai, Y. (1994). Discourse motivation for some cognitive acquisition principles. Studies in Second Language Acquisition, 16, 133-156.

Andersen, R. W., \& Shirai, Y. (1995). The acquisition of tense-aspect morphology: A prototype account. Language, 71, 743-762.

Bardovi-Harlig, K. (2000). Tense and aspect in second language acquisition: Form, meaning, and use. Oxford: Blackwell.

Bardovi-Harlig, K., \& Reynolds, D. W. (1995). The role of lexical aspect in the acquisition of tense and aspect. TESOL Quarterly, 29, 107-131.

Bowerman, M. \& Li, P. (1998). The acquisition of lexical and grammatical aspect in Chinese. First Language, 18, 311-350.

Bredeche, C. C. (2011). The use of le by L1 Chinese speakers and the acquisition of le by L2 Chinese learners. Ph.D. dissertation, City University of New York, New York.

Chen, J., \& Shirai, Y. (2010). The development of aspectual marking in child Mandarin Chinese. Applied Psycholinguistics, 31, 1-28. 
Clarke, J. L. (1981). Language. In T. S. Barrows (Ed.), College students' knowledge and beliefs: A survey of global understanding (pp. 25-36). New Rochelle, NY: Change Magazine Press.

Duff, P. \& Li, D. (2002). The acquisition and use of perfective aspect in Mandarin. In R. Salaberry \& Y. Shirai (Eds.), The L2 acquisition of tense-aspect morphology (pp. 417-454). Amsterdam: John Benjamins.

Erbaugh, M. S. \& Smith, C. S. (2005). Temporal interpretation in Mandarin Chinese. Linguistics, 43, 713-756.

Foote, R., \& Salaberry, R. (2009). Marking past tense in second language acquisition: A theoretical model. Studies in Second Language Acquisition, 31, 515-516.

Jin, L. (2006). The development of aspect marking in L2 Chinese by English native speakers. Beijing: Foreign Language Teaching and Research Press.

Jin, L., \& Hendriks, H. (2005). The development of aspect marking in L1 and L2 Chinese. Working Papers in English and Applied Linguistics, 9, 69-99.

Kroll, J. F., Michael, E. \& Tokowicz, N. (2004). The roles of study abroad experience and working memory capacity in the types of errors made during translation. Bilingualism: Language and Cognition, 7, 255-272.

Lee, E. H., \& Kim, H. Y. (2007). On crosslinguistic variations in imperfective aspect: The case of L2 Korean. Language Learning, 57, 651-685.

Li, P. (1990). Aspect and aktionsart in child Mandarin. Doctoral Thesis. Leiden University, Nijmegen, the Netherlands.

Li, P. \& Shirai, Y., (2000). The acquisition of lexical and grammatical aspect. Berlin and New York: Mouton de Gruyter. 
Lin, J. W., (2003). Temporal reference in Mandarin Chinese. Journal of East Asian Linguistics, 12, 259-311.

Luk, Z. P. (2010). Motion events in Japanese and English: Does learning a second language change the way you view the world? Unpublished M.A. thesis, University of Pittsburgh.

Luk, Z. P. \& Shirai, Y. (2009). Is the acquisition order of grammatical morphemes impervious to L1 knowledge? Evidence from the acquisition of plural -s, articles, and possessive 's. Language Learning, 59, 721-754.

Martelle, W. (2011). Testing the Aspect Hypothesis in L2 Russian. Doctoral dissertation, University of Pittsburgh, Pittsburgh, Pennsylvania. (Publication No. AAT 3485756).

McEnery, A. M. \& Xiao, R. (2004). Aspect in Mandarin Chinese: A corpus-based study. Amsterdam: John Benjamins.s

Salaberry, R. (1999). The development of past tense verbal morphology in classroom L2 Spanish. Applied Linguistics, 20, 151-178.

Salaberry, R. (2003). Tense aspect in verbal morphology. Hispania, 86, 559-573.

Salaberry, R. (2011). Assessing the effect of lexical aspect and grounding on the acquisition of L2 Spanish past tense morphology among L1 English speakers. Bilingualism: Language and Cognition, 14, 184-202.

Salaberry, R. \& Shirai, Y. (2002). The L2 acquisition of tense-aspect morphology. Amsterdam: John Benjamins.

Smith, C. S. (1991). The parameter of aspect. Dordrecht: Kluwer Academic.

Vendler, Z. (1957). Verbs and times. The Philosophical Review, 66, 143-160.

Wen, X. (1995). Second language acquisition of the Chinese particle le. International Journal of Applied Linguistics, 5, 45-62. 